Portland State University

PDXScholar

\title{
Making the Transition from East to West: Evangelical Christian High School Students from the Former Soviet Union
}

Sharon Kay Link

Portland State University

Follow this and additional works at: https://pdxscholar.library.pdx.edu/open_access_etds

Part of the Bilingual, Multilingual, and Multicultural Education Commons Let us know how access to this document benefits you.

\section{Recommended Citation}

Link, Sharon Kay, "Making the Transition from East to West: Evangelical Christian High School Students from the Former Soviet Union" (1995). Dissertations and Theses. Paper 5028.

https://doi.org/10.15760/etd.6904

This Thesis is brought to you for free and open access. It has been accepted for inclusion in Dissertations and Theses by an authorized administrator of PDXScholar. Please contact us if we can make this document more accessible: pdxscholar@pdx.edu. 


\section{THESIS APPROVAL}

The abstract and thesis of Sharon Kay Link for the Master of Arts in Teaching English to Speakers of Other Languages were presented July 13, 1995, and accepted by the thesis committee and the department.

COMMITTEE APPROVALS:
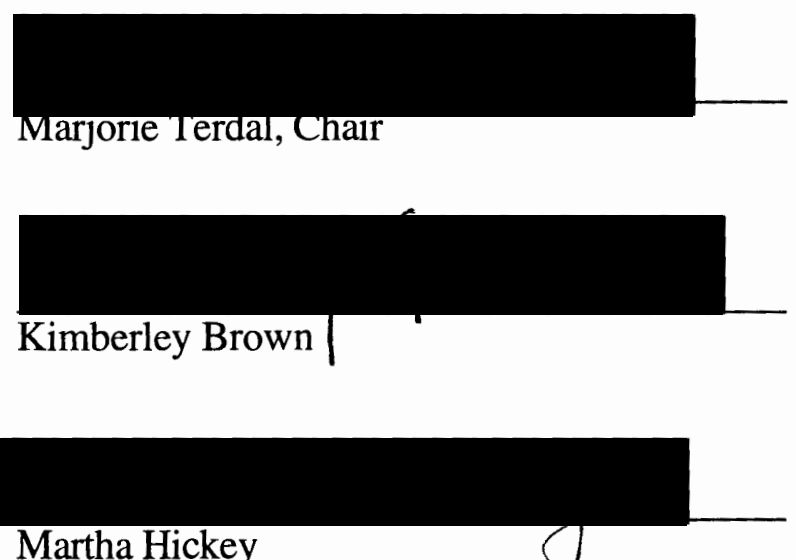

Representative of the Office of Graduate Studies

DEPARTMENT APPROVAL:

Beatrice Oshika, Chair

Department of Applied Linguistics

$* * * * * * * * * * * * * * * * * * * * * * * * * * * * * * * * * * * * * * *$

ACCEPTED FOR PORTLAND STATE UNIVERSITY BY THE LIBRARY

by

on

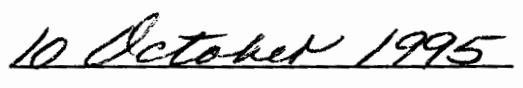




\begin{abstract}
An abstract of the thesis of Sharon Kay Link for the Master of Arts in Teaching English to Speakers of Other Languages presented July 13, 1995.
\end{abstract}

Title: Making the Transition From East to West: Evangelical Christian High School Students From the Former Soviet Union.

This study documents the educational and cultural experiences of Soviet Evangelical high school students, the most recent refugee population to the Portland-Vancouver school districts.

Soviet Evangelical high school students have experienced a slow and difficult transition to the American classroom. The students were often negatively characterized by their ESL teachers and other school personnel as "difficult" due to their classroom behaviors. Many times, these behaviors did not meet the ESL teacher's expectations, resulting in a culture clash between the teacher and the Soviet Evangelical students.

The study found that Soviet Evangelical high school students came to the United States with high expectations of a new life, but little knowledge of the U.S. or the American classroom. Feelings of loneliness, homesickness and frustration quickly set in upon encountering the new language, new school routines and rules and regulations, some of which made no sense to the students. The educational and cultural values that form the Soviet Evangelical students' orientation toward learning and the classroom were found to play a strong role in the transition process and also helped to account for 
the behaviors ESL educators found so difficult to deal with. These factors, combined with the students' strong in-group identity as Soviet Evangelicals, all contributed to their slow and difficult transition to the American classroom.

The study concludes with recommendations for ESL educators and other school personnel focusing on easing the transition for Soviet Evangelical students. Teaching new students the skills and background knowledge necessary for interacting in an American classroom is stressed, along with using the students' church as a resource in order to foster a trusting relationship with both students and their parents. 
MAKING THE TRANSITION FROM EAST TO WEST: EVANGELICAL CHRISTIAN HIGH SCHOOL STUDENTS FROM THE FORMER SOVIET UNION

by

SHARON KAY LINK

A thesis submitted in partial fulfillment of the requirements for the degree of

MASTER OF ARTS

in

TEACHING ENGLISH TO SPEAKERS

OF OTHER LANGUAGES

Portland State University

1995 


\section{ACKNOWLEDGMENTS}

I would like to express my appreciation to my committee members-- Kimberley Brown, Martha Hickey, and especially Marge Terdal, who patiently taught me how to write academically. Thanks also go to my colleague in Slovakia, Toby Brody, whose insightful comments on early thesis drafts were of great help. Finally, I would like to thank the students and school personnel who willingly took time away from their jobs and school work to participate in this study. It was truly a pleasure for me to work with them.

This thesis is dedicated to my mother and father. 


\section{LIST OF TABLES}

TABLE

I STRUCTURE OF THE SOVIET SYSTEM OF EDUCATION. . . . . 22

II LANGUAGE LEARNING PREFERENCE SURVEY..........58 


\section{TABLE OF CONTENTS}

\section{PAGE}

ACKNOWLEDGEMENTS. .......................... ii

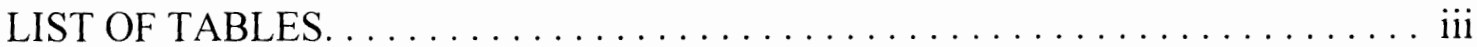

\section{CHAPTER}

I INTRODUCTION $\ldots \ldots \ldots \ldots \ldots \ldots \ldots \ldots \ldots \ldots \ldots \ldots \ldots$

The Problem $\ldots \ldots \ldots \ldots \ldots \ldots \ldots \ldots \ldots \ldots \ldots$

Definition of Terms ........................ 5

Immigrant

Refugee

Soviet Evangelical Christian

Soviet/Russian

The Scope of This Study . . . . . . . . . . . . . . . . 8

II A REVIEW OF THE LITERATURE . . . . . . . . . . . . 10

Historical and Cultural Overview of Soviet Evangelicals. . . . 11

History

Religious Practices

Worship

Culture

Family Values

Gender Roles

Soviet Cultural Characteristics.

Egalitarianism 
Dual Personality

The "Russian Soul"

The Education System of the Former Soviet Union. . . . . . . 20

Organization

Curriculum

Teaching and Discipline Methods

A Typical Soviet Lesson

Acculturation. 26

Special Acculturation Problems of Soviet Evangelicals

III RESEARCH AND DATA COLLECTION PROCEDURES. ..... 30

Research Design. ....................... 30

Time Frame

Research Site

Research Participants

Data Collection Procedures. . . . . . . . . . . . . . . 37

Classroom Observation

Language Learning Preferences Survey

Interviews

Limitations of the Study.

IV EXPECTATIONS AND INITIAL IMPRESSIONS. 45

American Culture. .......................46

Emigrating to the U.S.-- Great Expectations

Education. 48

School in the U.S.-- Initial Impressions

Differences between U.S. and Soviet Secondary Schools 
$\mathrm{V}$ ORIENTATION TOWARD LEARNING. ............. 56

Language Learning Preference Survey............ 56

The Teacher ..........................60

Good and Bad Teachers

Attitudes Toward Education and ESL ..............64

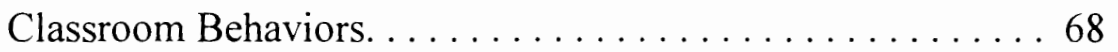

Discrimination

Cheating

Absenteeism

Resistance to authority

Talking

Other Behaviors Identified by ESL Teachers. . . . . . . . . . 77

Disorganization

Leaving the room without permission

VI THE ACCULTURATION PROCESS $\ldots \ldots \ldots \ldots \ldots \ldots \ldots$

Future Challenges Facing Soviet Evangelicals. . . . . . 80

Future Plans. . . . . . . . . . . . . . . . 81

Making The Transition. ..................... 83

The Future Of Soviet Evangelical High School Students. . . . 86

VII CONCLUSION AND RECOMMENDATIONS . ........... 90

Recommendations .......................96

Future Research

Recommendations for ESL educators and others working with Soviet Evangelical High School Students

VIII EPILOGUE.......................... 100 

APPENDICES

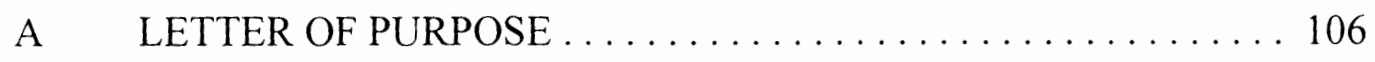

B SAMPLE OBSERVATION CODING SHEET . . . . . . . . . 107

C LANGUAGE LEARNING PREFERENCE SURVEY . . . . . . . 108

D INTERVIEW GUIDING QUESTIONS . . . . . . . . . . 109

E SOVIET RELIGIOUS CONSERVATIVE GROUPS VERSUS



F INDIVIDUALIST VERSUS COLLECTIVIST VALUES. . . . . . 112 


\section{CHAPTER I}

The purpose of this study is to document the educational and cultural experiences of adolescent Evangelical Christian students from the former Soviet Union, who are currently enrolled in high school English as a Second Language (ESL) classes. The two goals of this study are 1) to detail the experiences of Soviet Evangelical Christian high school students who have transitioned from the totalitarian and collectivist oriented Soviet culture and classroom to the more open, individualistic American ones, using the students' own words: and 2) to present a cultural and educational study of these students which will provide ESL educators and other school personnel working with them a frame of reference that will give them a greater understanding of this most recent and relatively unknown ESL student population. Ideally, this study will enable all involved with Soviet Evangelical high school students to work more effectively with them.

\section{THE PROBLEM}

Between the years 1988 and 1994 approximately 7,000 Soviet Evangelicals have resettled in Oregon (Levinsky \& Rubenstein, 1994). Figures from the Oregon State Refugee Program illustrate the rapid influx of Soviet Evangelicals during a four-year period. In 1987, they constituted only one percent of the total refugees in the state. This grew to $14 \%$ in $1988,55 \%$ in 1989 , and $61 \%$ in 1990 (Hardwick, 1993, p.14). 
Soviet Evangelical immigration to Oregon reached its peak in 1992. with 1,296 refugees resettled, and has been slowly declining since.

This sudden and unexpected large influx of Soviet Evangelical Christian refugees has resulted in a demographic shift in many high school Portland-Vancouver ESL classrooms. Previously, Asian students from Japan, Korea, and Vietnam constituted the majority of ESL learners, with other groups such as Middle Eastern, often making up less than one percent of a class.

This situation was compounded by the fact that their ESL teachers and other school personnel knew virtually nothing of them as a cultural or refugee group. Due to negative propaganda and the lack of cooperative educational exchanges during the Cold War era, along with the scarcity of research on Soviet Evangelicals, most United States (hereafter U.S.) teachers were unfamiliar with the culture and education system of the former Soviet Union. The recent and rapid changes within the country added to this lack of knowledge (Hoot, 1993). Therefore, educators were unprepared for the unique challenges this new student population would provide.

Soviet Evangelical high school students brought to the U.S. a similar lack of cultural knowledge and many misconceptions based on Cold War propaganda. From their experiences as a persecuted minority in the former Soviet Union, many Soviet Evangelical students and their parents brought feelings of distrust and a decidedly negative attitude towards school and school personnel. Taunts from their peers and discrimination in the classroom by their teachers were part of the hostile school environment the students faced because of their religious beliefs. School officials 
chastised, harangued, and harassed both students and their parents in an effort to dissuade their Christian convictions. Home visits, parent-teacher conferences, and even the threat of removal of the children from the home were all part of this pressure (Specific Questions, 1993).

Within the U.S. school system, Soviet Evangelical high school students are often negatively characterized as being 'difficult' by their ESL teachers and school counselors. This label comes primarily from their classroom behaviors, which often include a resistance to the teacher's authority, cheating, a demand for special treatment, and frequent off-task behaviors, such as talking at inappropriate times during class, reading magazines, and leaving the classroom without permission. Additionally, seemingly low motivation and high absenteeism are cited (see, for example, Specific Questions, 1993; Zvereff, 1992).

These behaviors are compounded by the difficulty Soviet Evangelical students have in making the transition from the closed, totalitarian Soviet educational system to the more open, individualistic American one. Skills that are often taken for granted in the U.S. classroom, such as maintaining an organized notebook, meeting assignment deadlines, self-monitoring of classroom progress, and selecting classes for an upcoming semester are a few examples of the new and problematic tasks for Soviet Evangelical high school students.

Finally, the students' own often naive and unreasonable expectations of American schools, again the result of misinformation and misconception, lead to an often long and difficult period of adjustment and acculturation to the U.S. high school classroom 
(O'Donnel, 1992).

Normally, those working with refugee populations rely on scholarly research findings to educate themselves as to the needs of the specific group (Roberts, 1991). As mentioned above, scant literature and scholarly studies of Soviet Evangelicals currently exist. Research focusing exclusively on high school Soviet Evangelicals is even more rare. Roberts (1991) and Wiggins (1994) are two of the few studies of Soviet Evangelicals in the Portland, Oregon area. Roberts, focusing on the refugees' resettlement and acculturation processes, found that the U.S. educational system was ill-prepared to meet the unique needs and learning styles of the students and the challenges they posed. Wiggins, examining the educational and core values of adult Soviet Evangelical students, states that because of the contrast in Soviet and American educational systems and the differing educational and core values of Soviet Evangelical and American students, ESL educators need to consider these two factors when deciding which teaching methodologies to use in the classroom. Both authors call for continued research on Soviet Evangelicals.

ESL instructors in Portland-Vancouver secondary schools have tended to rely on guest speakers and short, unpublished papers, often authored by their peers, in an attempt to quickly educate themselves about their Soviet Evangelical students. While certainly helpful, these papers are of limited use because they often provide only a surface level overview of Soviet Evangelical culture and contain sweeping generalizations or even negative teacher bias.

Research and literature about Soviet Jewish immigrants are more plentiful, but also 
of limited use. While both groups share some characteristics of general Soviet culture. they are two distinct cultural and religious groups. Because of this, information provided in many studies of Soviet Jews is not always applicable to Soviet Evangelicals.

The slow decline since 1992 of Soviet Evangelicals resettling in Oregon is not expected to affect the high numbers of Soviet Evangelical students in Portland-Vancouver high school ESL classes. Secondary migration, or refugee relocation to Oregon from other states, and family reunification ensure that the Soviet Evangelical high school population figures will continue to be significant.

The quick rise of Soviet Evangelical classroom domination and continuing enrollment clearly illustrates the need for more research in order to foster cultural and educational sensitivity. It is also the responsibility of ESL educators and other school personnel working with Soviet Evangelicals to have an understanding of their students' educational and cultural needs.

\section{DEFINITION OF TERMS}

Four terms are essential to the understanding of Soviet Evangelical Christians. These include: immigrant, refugee, Soviet Evangelical Christian, and Soviet/Russian.

\section{Immigrant}

The U.S. government defines immigrants as those people who voluntarily leave their native land in order to better their lives in the U.S. Once in the U.S.. immigrants must rely on their own financial resources, family help, employer assistance, or community support (Changes abroad, 1990). 


\section{Refugee}

As defined by the U.S. government in the 1980 Refugee Act, refugees are individuals fleeing their homeland because of a well-founded fear of religious or political persecution. Refugees receive resettlement funds and status as lawful permanent residents after one year in the U.S. retroactive to the date of their arrival (Changes abroad, 1990).

\section{Soviet Evangelical Christian}

Soviet Evangelical Christian refers to the members of the various Christian denominations from the former Soviet Union. Pentecostals, including Assembly of God, Four Square, and Full Gospel sects, along with Baptists, 7th Day Adventists, and several independent denominations comprise this group. Pentecostals, characterized by their strict interpretation of the Bible and speaking in tongues, are the largest Evangelical denomination resettled in Oregon (O'Donnel, 1992). The term Soviet Pentecostal is commonly used by school and social service agencies in the Portland-Vancouver area in reference to all Soviet Christian refugees. In this study, the more correct and inclusive term "Soviet Evangelical", will be used. Distinctions between denominations will not be made.

\section{Soviet/Russian}

According to Richmond (1992), the terms Soviet and Russian were often used interchangeably by both Americans and Soviets when referring to the former Soviet Union. Even though in December 1991 the Soviet Union ceased to exist as a country and became the Commonwealth of Independent States. both terms continue to be used. 
For the purpose of this thesis the more comprehensive term "Soviet" will be used. Distinctions between the more than one hundred nationalities and cultures that comprised the former Soviet Union will not be made.

\section{THE APPROACH OF THIS STUDY}

This thesis is based on the belief that a key to working effectively with any student population in the high school ESL classroom is to understand their cultural and educational backgrounds. Knowledge of the students' orientation towards learning and their impressions and expectations of U.S. culture and education is also important. For school personnel involved with Soviet Evangelical students, this is of particular importance, because these students "cannot be understood without reference to their deep religious beliefs, principles, and practices that permeate and guide their lives" (Hoot, 1993, p.2). Understanding the harassment and persecution endured by Soviet Evangelical students from their Soviet teachers for their religious convictions is also necessary in order to understand their distrust and negativity towards education and school authority figures. Much of the students' classroom behavior that their ESL. teachers find difficult to comprehend and cope with becomes comprehensible once background knowledge of Soviet Evangelical culture and educational experience is obtained.

Therefore, a major goal of this thesis is to examine the students' cultural and educational backgrounds, along with documenting their experiences of transitioning from the Soviet culture and school system to the American ones. Since little information and research about Soviet Evangelicals, in particular high school age 
Evangelicals, currently exists, a secondary goal of the researcher is to contribute to this small pool of knowledge. By researching the students' cultural and educational histories and relating their personal experiences, this thesis will serve as a reference for high school ESL instructors and other school personnel interested in learning about their Soviet Evangelical students. It will also give educators a tool that will enable them to work more effectively with and better serve the educational needs of their students.

\section{THE SCOPE OF THIS STUDY}

The three research questions used to guide this study are framed around the main question of "Who are Soviet Evangelical high school students?" Within the three general questions, more specific questions are included.

1) What expectations and impressions of American culture and education system do Soviet Evangelical high school students have?

a. What background knowledge of the U.S. did they bring with them?

b. What were their initial impressions of their new schools?

c. What differences between Soviet and American high schools do they see?

2) What educational background do Soviet Evangelical high school students bring to the U.S.?

a. What are their preferred learning styles?

b. What are their attitudes toward school and the ESL classroom?

c. How do they account for the classroom behaviors their ESL teacher has identified as problematic?

3) How do the above factors affect their adjustment and acculturation to American schools and culture after students have resided for one year or more in the U.S.?

a. What are the students' plans for the immediate future?

b. What personal changes have they undergone since emigrating to America?

c. How do the students' ESL teacher and other school personnel assess the students' future? 
Data to answer these questions were gathered in three manners: 1) interviews with Soviet Evangelical high school students, their ESL teachers and other school personnel, and persons outside the Soviet Evangelical community with knowledge of Soviet culture and education system; 2) classroom observations; 3) a questionnaire surveying the students' preferred learning styles. The research procedure is more fully discussed in the Research Design and Data Collection Procedures chapter. 


\section{CHAPTER II}

\section{A REVIEW OF THE LITERATURE}

Chapter I described the framework around which this study is based. Chapter II provides a brief context for understanding Soviet Evangelical culture, religious beliefs and educational background.

The review of the literature is based upon the three research questions this study addresses: 1) What expectations and impressions of American culture and education system do Soviet Evangelical high school students they have? 2) What educational background do Soviet Evangelical high school students bring to the U.S.? 3) After residing for one year or more in the U.S., how do the above factors affect their adjustment and acculturation to American schools and culture? To address these questions, this chapter is divided into the following sections: 1) A historical and cultural overview of Soviet Evangelicals, 2) A description of the education system in the former Soviet Union, 3) A summary of the process of adjustment and acculturation by refugees and immigrants.

It should be noted that many of the statements put forth, especially those in the culture section, are not absolutes. Instead, they are a list of characteristics or generalizations. Thus, the following may be true to varying degrees for individual Soviet Evangelicals. 


\section{HISTORICAL AND CULTURAL OVERVIEW OF SOVIET EVANGELICALS}

\section{History}

Religion in the former Soviet Union is normally identified with the official Communist party policy of atheism or with Russian Orthodoxy, the state religion of Russia for almost 1,000 years. Other Christian sects have existed for many years throughout the Soviet Union, including Catholic, Lutheran, and Baptist (Richmond, 1992).

Evangelicalism was introduced to Russia in the 19th century by Baptist and Plymouth Brethren (Christian Refugees, 1989). Membership is comprised of mainly ethnic Russians, Byelorussians, and Ukrainians (Levinsky \& Rubenstein, 1994). Pentecostalism, brought to Russia in 1911 by American Pentecostal missionaries, grew rapidly in a brief span of years, boosted by the support of believers from outside of Russia. The first church was established in Vyborg, near the Finnish border. The new religion reached St. Petersburg in 1914, then quickly spread over the next several years into Novgorad, Moscow, and the Caucausus. Its greatest growth came from Ivan Voronaev, a Russian-born Baptist preacher. After fleeing Czarist persecution in 1911 to the U.S., Voronaev returned as an Assemblies of God minister in 1922 to Odessa, to introduce Pentecostalism to Northern Russia. Only five years later, over 350 churches with approximately 7,000 members had been established through his work (Christian Refugees, 1989; Hardwick, 1993; Levinsky \& Rubenstein, 1994).

\section{Persecution of Soviet Evangelicals}

The persecution of Soviet Evangelicals began with their inception in the 19th century 
and did not officially end until 1991, with the disintegration of the Soviet State.

Persecution came from two sources. The Russian Orthodoxy, who viewed Evangelicals as dissenters, harassed them until the 1917 Bolshevik Revolution. The new Communist government, wishing to diminish the influence of the Russian Orthodoxy, at first tolerated Evangelicals because it viewed them as being anti-Orthodox. Evangelicals were given the freedom to openly practice their faith and hundreds of churches were established (Christian Refugees, 1989).

This policy of tolerance, however, ended abruptly in 1929 with the rise of Stalin and the passing of the Law on Religious Associations. The growth of Christian religions was curtailed and harsh persecution of Believers ensued, with thousands of Evangelicals sent to prisons in Siberia. These imprisonments had the unexpected result of actually increasing membership totals, through missionary work by imprisoned Evangelicals to other inmates (Hardwick, 1993).

Government religious policies towards Christians reversed themselves various times from 1940 to 1990. During World War II, Stalin, attempting to unify the country, increased support for all religious groups, as he viewed religion to be a potentially useful tool for unification. He reversed this policy during the last five years of his rule and the previous rigorous and harsh persecution of religious groups resumed. After his death in 1953, conditions improved slightly, but again deteriorated during the Khrushchev era of 1959-64. Persecution of Evangelicals was once again conducted.

The plight of Soviet Evangelicals first came to the attention of the West in 1963 during the Khrushchev era. A group of Pentecostals suddenly and unexpectedly entered 
the American embassy in Moscow seeking religious asylum. The Soviet government denied their accusations of religious persecution, and the Pentecostals were not granted religious asylum.

Asylum was again sought in 1978 by a group of Pentecostal families. Two of the families, who came to be known as the Siberian Seven, lived for five years in the basement of the American embassy while the U.S. and Soviet governments argued over them. Both of these events drew worldwide media coverage accompanied by letter writing campaigns by U.S. and European religious organizations that would last until the Gorbachev era (Hardwick, 1993; Mayr, 1992).

The most dramatic changes in government policy and attitude towards religious groups came during the late 1980's with glasnost and Gorbachev's presidency. In 1987, the government began releasing religious prisoners from jails and allowed a few Evangelical families to emigrate. This was followed a year later by the celebration of the Millennium of Christianity in the Soviet Union. Two years later, state-sponsored atheism was essentially ended with the passing of the Law on Freedom of Conscience and Religious Organizations by the Soviet Legislature. This law prohibited the state from interfering in religious affairs, and gave equal recognition to all religions. It was during this time that Christian groups, including Evangelicals, began to see a renewed growth of membership and activities. It also marked the beginning of what would be a substantial flow of Soviet Evangelicals to the U.S., as Gorbachev opened the way for large scale immigration of its members to the U.S. (Christian Refugees, 1989; Hardwick, 1993). 


\section{Religious Practices}

All Soviet Evangelical denominations of Baptists, Pentecostals, and 7th Day Adventists, adhere to the main tenets of Christianity (Wiggins, 1994). Pentecostals differ from other Evangelicals because of their emphasis on speaking in tongues, faith healing, prophecy, and the Baptism of the Holy Spirit. Some Pentecostals also practice footwashing as part of the communion service, based on Christ's washing the disciples' feet at the Last Supper (Christian Refugees, 1989).

\section{Worship}

The heart of a Soviet Evangelical's life is the church, which they may attend up to four times a week. A typical Soviet Evangelical worship service differs considerably from American Evangelical services. Soviet Evangelicals demonstrate a serious and solemn attitude towards worship. Services often last three hours or more and are characterized by an almost mournful atmosphere. Humor or any form of levity is conspicuously absent. Members dress modestly and women cover their heads with scarves or "babushkas." Men and women sit on separate sides of the sanctuary.

During a service, sermons may be delivered by three or four men. Both church officials and laymen participate. Women do not normally take leadership roles. Prayer, congregational singing, choir performances, and poetry recitations are intermingled with the sermons. Worshipers kneel or stand during often fervent prayer.

\section{Culture}

Soviet Evangelical culture is comprised from a blending of religious and ethnic characteristics. Members exhibit behaviors and traits that are representative of the 
Soviet population as a whole, but their strong adherence to their religious identity and beliefs is what defines them as a unique group. These two factors also serve to distinguish them from other cultural groups in the former Soviet Union.

A strong sense of group identity is culled from two areas: membership in their religious group and the harsh experiences suffered under years of persecution. It is their faith and religious beliefs that form the dominant backdrop for world views and serve as the guiding principal for daily life (Valsamakis, 1992). "Personal holiness" or keeping one's self pure, is of the highest importance in Soviet Evangelical culture, and members continually strive to maintain this purity.

Society for Soviet Evangelicals is divided into two groups: "believers" and "non-believers" (Christian Refugees, 1989; Specific Questions, 1993). Outsiders, or non-believers, which include government institutions, are viewed with distrust and skepticism. This distrust is again the result of religious beliefs and years of persecution at the hands of the Soviet State. Wanting to avoid the "worldly" influences of and possible contamination by outsiders, Evangelicals generally do not socialize beyond their own church and community (Valsamakis, 1992). Instead, closely knit friendships and networks are created among families, church, and community members (Hardwick, 1993).

\section{Family Values}

Family values within Soviet Evangelical culture are traditional by American standards. Families tend to be large, averaging six children, and are close-knit. Ties to the extended family are also very close (Christian Refugees, 1989). A hierarchical, 
autocratic parenting style is prevalent among many families. Parents are strict in child rearing and assumed to know what is best for their children. A child, in turn, understands that parents hold the power and that subservience on a child's part is a valued act. Modesty among children is also a desired behavior. Children are considered to be a blessing from God and should feel valued as members of their family (Valsamakis, 1992).

Older family members, especially the "babushka" or grandmother, play an important role within the Soviet Evangelical family. Babushkas often serve as a stable figure in both home and spiritual life (Christian Refugees, 1989). Older people as a whole are to be respected and are seen as being wiser than the young. Adult children should either live with or visit their parents regularly. Children are expected to take care of their parents when they become old (Valsamakis, 1992).

\section{Gender Roles}

Soviet Evangelical culture clearly defines the role of men and women within society and family. This is based on Ephesians 5:22-23, which states that the husband is the head of the wife and that wives are subject to their husbands. Women are responsible for household duties and childcare. Husbands may sometimes help their wives in the home, but not to a great extent. Older children, usually girls, are expected to help their mother in caring for younger siblings. While this separation of men's and women's roles and duties is seen as natural to Soviet Evangelicals, it is considered traditional and conservative by American standards (Christian Refugees, 1989; Specific Questions, 
Gender separation starts early in Soviet Evangelical culture, beginning with young children. From an early age, children have separate toys based on gender (Valsamakis, 1992). School children tend to exhibit the same gender roles as their parents, through dress and behavior. Girls, for example, often do not speak up in class in the presence of boys, reflecting the Soviet Evangelical belief that men have priority to speak over women (Irwin, 1991).

\section{SOVIET CULTURAL CHARACTERISTICS}

Considering that the former Soviet Union is comprised of over 100 different cultures, it would be difficult to define the cultural composition of the "average" Soviet citizen. There are, however, certain cultural characteristics true of many Soviets, particularly Russian and Ukrainian, who form the majority of the Soviet Evangelical high school students in the Portland-Vancouver schools. Therefore, the descriptions put forth by various authors may be seen as applicable to most Soviet Evangelical students currently attending local high schools.

Some literature attempts to explain the Soviet character by comparing a totalitarian, Soviet State society with a democratic, American society. While this is helpful, it provides only a surface level picture of the people often referred to as "enigmas" (O'Neil, 1992). O'Neil writes, "Russian life and people are full of paradoxes and contradictions not easily understood by Western minds" (p. 16). Richmond (1992) summarizes Russian character in the following manner:

The Russian character, formed over centuries by unique experiences, has made Russians different from other Europeans as well as Americans. (p.xv) 
Richmond also cautions, "There are no easy shortcuts to understanding the Russians" (p.xiv).

Three notable cultural characteristics of the Soviet psyche include egalitarianism, the dual personality, and the "Russian soul."

\section{Egalitarianism}

Contrary to popular belief, Soviet egalitarianism, or collectivism, was not a product of Communist ideology, although it was reinforced in their political policies. The deep roots of egalitarianism lie in the mir, the agricultural village communes that date back to Tsarist times. The mir featured consensus decision making and served as the nucleus of the communal society.

The mir tradition has resulted in an egalitarian or collectivist orientation that contradicts the American sense of individualism. The word "individual" carries a pejorative meaning in the Russian language. Instead, Soviet culture features a preference for interdependence within a group and the subordination of personal goals to those of the collective unit (Valsamakis, 1992). Many Soviets may believe it is morally wrong to get ahead at the expense of others. There is a strong identity with one's group and the norms of the group become internalized. "Dissident or 'inakomyslyaschi' actually means persons who think differently" (Richmond, 1992, p.27).

Belozersky (1989) claims that this emphasis on the collective leads to a negative Soviet trait of overdependency. She states that as Soviet culture strongly encourages its citizens to subject their individual interests to the interest of the collective, obedience 
and dependency are fostered, while autonomy and initiative are decreased. This accounts for, in her view, the overdependent behavior many Soviet Evangelicals exhibit in the U.S.

\section{Dual Personality}

The dual personality Soviets may exhibit is a product of the Soviet state. Decades of continuous monitoring of individuals led to the two different sides of their personality. One face was presented to the world and the other was reserved for family and friends. The first, or public one, conformed to the politically correct Socialist principles. The second one reflected an individual's own viewpoint and was reserved for private occasions (Belozersky, 1989; O'Neil, 1992).

This "living in the double" or dual personality has resulted in a strong cultural prohibition against sharing private thoughts and feelings with strangers. It also causes difficulty in establishing trust, especially with authority figures. Instead, there is a strong reliance on family and friends and a high value on friendship. The dual personality also explains why Americans working with Soviet Evangelicals complain that they seem cold and distant at first (Belozersky, 1989).

\section{The "Russian Soul"}

Richmond (1992) writes at length about russkaya dusha or the "Russian soul", which he calls "the essence of Russian behavior" (p.46). Dusha is best known to Westerners from the emotion and sentimentality often found in the Russian arts. It also encompasses traditional peasant values of compassion, family, love of nature, self-sacrifice, and a sense of duty. Richmond credits the Russian soul with giving 
political dissidents Andrei Sakharov and Aleksandr Solzhenitsyn courage and moral strength in the face of harassment and persecution.

To comprehensively define dusha, Richmond relies on a definition by Tatyana

Tolstaya, a leading Russian writer who describes dusha as:

sensitivity, reverie, imagination, an inclination to tears, compassion, submission mingled with stubbornness, patience that permits survival in what would seem to be unbearable circumstances, poetry, mysticism, fatalism, a penchant for walking the dark, humid back streets of consciousness, introspection, sudden, unmotivated cruelty, mistrust of rational thought, fascination with the word--the list could go on and on--all these qualities that have frequently been attributed to the "Slavic soul." (p.48)

Richmond contrasts $d u s h a$ with American values, stating:

Russians have a rich spirituality that does indeed contrast with American rationalism, materialism, and pragmatism. Russians suffer but seem to enjoy their suffering. Obsessed with ideas, their conversation is weighty and lengthy. The rational and pragmatic approach does not do for them. More often, it is personal relations, feelings, and traditional values that determine a course of action. Americans are more likely to depend on the cold facts and to do what works. (p.47)

\section{THE EDUCATION SYSTEM OF THE FORMER SOVIET UNION}

According to Richmond (1992), the purpose of education under the Soviet system was to indoctrinate students with socialist political ideology and social values beginning in kindergarten, in order to form a new "Soviet person" (p.91). This new Soviet person would then be better able to contribute to the building of socialism. Soviet officials recognized that outside of the family, school was the most important social institution for shaping the social, moral, and ideological development of children. and used it as a means to teach and to reinforce socialist principles. It is for this reason that Soviet students' behaviors and characteristics were shaped, more so than in other cultures, by 
their school experience.

\section{Organization}

The education system of the former Soviet Union was centralized and controlled in Moscow, and uniform throughout the country. The extent of this uniformity is illustrated in the following description from Landon Pearson:

It used to be possible...for a youngster to close his geography book in Moscow one morning, fly the long distance to Novosibirsk...go to school the next day, and find his new class studying the same page he had left the day before. (Richmond, 1992, p.91)

The highly developed system was divided into two levels (see Table 1: Structure of the Soviet System of Education): Preschool, ages 0-6 years, and General Education, split into four years of Primary School, ages 7-11, and seven years of Secondary School, ages 12-18. Upon finishing Secondary School students could choose to continue their education in one of two tracks: higher education (University) or technical training at either a specialized technical school (Technicum) or a vocational technical (vo-tech) school. Technicums concentrated on lower managerial and semi-professional jobs and lasted three to four years. Vo-tech schools trained students for blue collar types of jobs and lasted one to two years. School attendance was compulsory for all children aged 6-17 years. All school fees were paid by the state, except for school uniforms. The nine-month school year ran from September to June and Russian was the language of instruction in most schools (Steverick, 1992).

\section{Curriculum}

All Soviet schools used a standard curriculum, heavily laden with Socialist ideology 
TABLE 1: STRUCTURE OF THE SOVIET SYSTEM OF EDUCATION

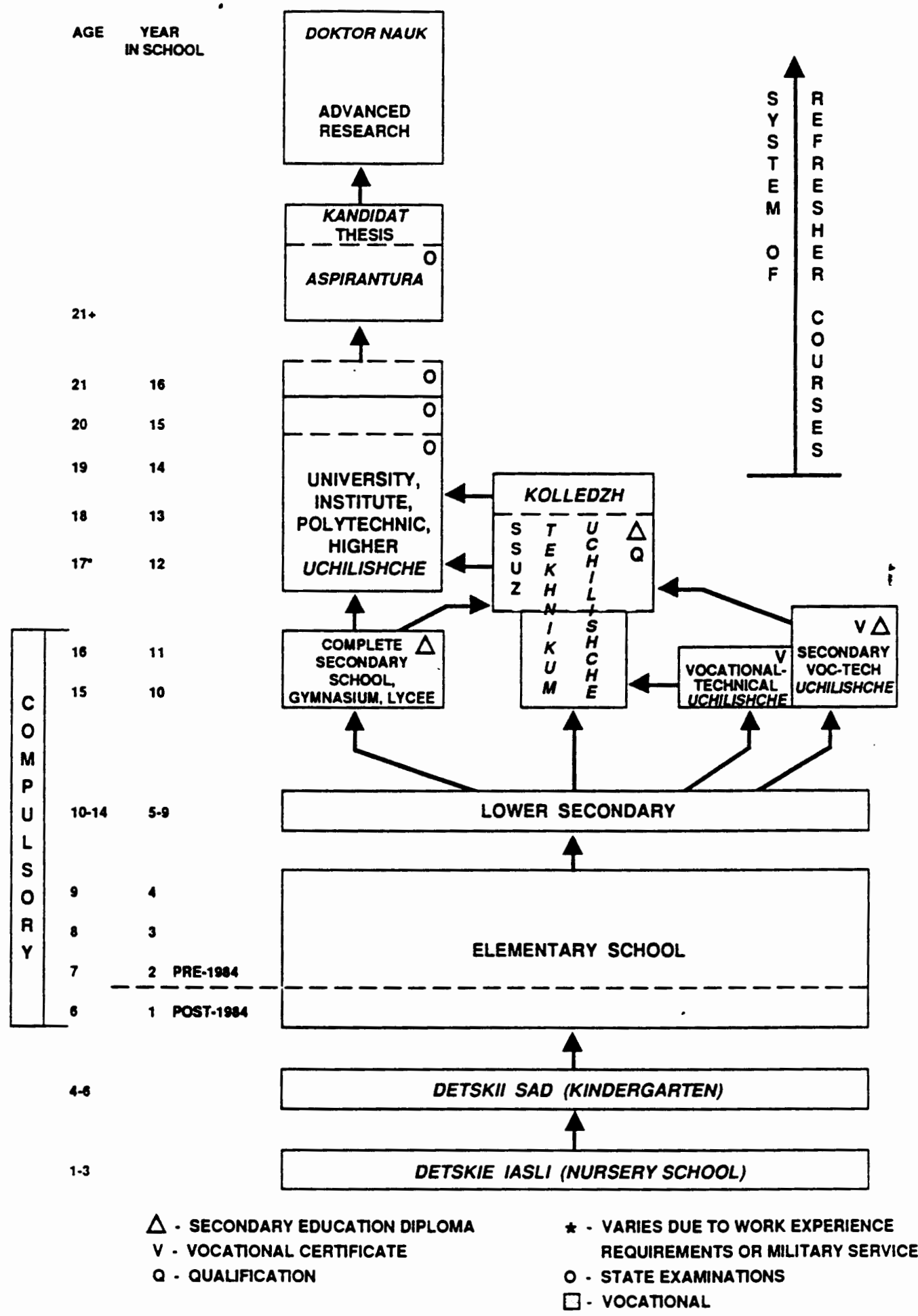

From: Popvych, E. \& Levin-Stankevich, B. (1992). The system of education: A PIER world education series special report. Washington D.C.: American Association of Collegiate Registrars \& Admission Officers. 
and controlled by party authorities in Moscow. Beginning in kindergarten with readings about "Grandpa Lenin," students studied Marxist-Leninist doctrine, fundamentals of Soviet state and law, and interpretations of current political issues from the Communist party point of view (Richmond, 1992).

The curriculum combined features of the dominant Russian culture and Marxist-Leninist ideology. Drawing on the Russian tradition of teaching 'vospitaniye' or upbringing (similar in nature to civic education in the U.S.) the Soviet state manipulated 'vospitaniye' in order to serve the politics of the Party. Students were also taught collectivist social values through required membership in three groups: the Octobrists (1st and 2nd grades), Young Pioneers (joined at third grade) and 'Komsomol' or Young Communist League (joined at age 14). Activities such as clean-up work after school, critiquing their peers' attitudes towards learning, and lectures on Lenin and the Soviet Motherland reinforced regular classroom curriculum and strengthened the students' collectivist behavior and orientation (Richmond, 1992).

\section{Teaching and Discipline Methodologies}

Teaching methodology in Soviet schools relied heavily on rote learning and recall responses. This is primarily due to the Russian cultural preference for the spoken form of communication and the favoring of oral over written exams. There was a heavy use of teacher-directed question and answer drills, using mainly display type questions. There was also little or no discussion. "Teachers taught the required curriculum with little concern for the individual needs of the pupil" (Richmond, 1992, p.92). In the Soviet classroom the role of the teacher was the giver of knowledge; the students 
sponges soaking it up (Irwin, 1991).

Discipline was harsh, especially by American standards. It has been described as authoritarian, rigid, punitive, and abusive towards children, employing methods such as fear, ridicule, and sometimes physical abuse (Bleckman, 1994, personal interview ; O'Neil, 1992).

Discipline served two purposes: to instill a respect for authority and to motivate students. Pearson (cited in Richmond, 1992) writes that from their earliest school years Soviet students were taught to respect the authority of the teacher and to observe the rules of the classroom:

A respectful and, indeed, slightly fearful attitude to adult authority is inculcated into Soviet children from the moment they set foot into an educational establishment. (p.92)

Students quickly learned that for each question asked by the teacher there was only one right answer. Students who knew the 'right' answer were assured good grades, while those who did not faced sometimes harsh admonishment from the teacher, including being called stupid or lazy and accused of not studying hard enough (Bleckman, 1994, personal interview). Muckle (1990) calls the frequent awarding of good grades for correct answers the "carrot and stick" method of discipline and motivation.

Muckle also found that a teacher's personality type could reflect his/her approach to discipline. "Some," he observed, "can rebuke a child quietly, others play hell so the whole school knows about it" (p.16).

O'Neil (1992), interviewing Soviet adults and children about their educational experience reported that most felt it was "negative and unhealthy for their personal and 
professional development" (p.15).

\section{A Typical Soviet Lesson}

The following description of a typical lesson in a Soviet secondary classroom is a compilation based on Muckle (1990), Bleckman (1994, personal interview), and descriptions provided by the Soviet Evangelical students interviewed for this thesis.

As the Soviet system was highly uniform, the classroom routine did not vary much from class to class or school to school. A lesson in a typical Soviet class began with the students rising when the teacher entered the classroom and sitting down only after receiving permission from the teacher to do so. The students, about $35-40$ per class, sat at two-person tables arranged in rows. After taking attendance and collecting the notebooks that contained the students' homework, the teacher would state the theme of the day's lesson, in the following manner as observed by Muckle:

Today we will begin studying the Soviet state and its stages of development, its main aim and objectives, the functions of the state, its origins, history, and essence. (p.98) Students would busily write down the teacher's words knowing they would be tested over them.

The lesson would proceed with the teacher drilling the class over the material in the textbook. As oral responses were most favored in the Soviet classroom; drills were mainly oral. Display type questions were normally used and were not designed to test the pupils' understanding or ability to deduce answers. As Muckle states, "They merely coax the dutiful into finding the appropriate lines of the textbook in order to read them outloud" (p.99). Students were expected to answer from memory, often quoting 
verbatim from their textbook or notes.

The teacher's questions drew little response from the majority of the class. A spontaneous response may rarely occur, rather than a recitation of a quote from the textbook. The drilling continued until the end of the period, when homework was assigned and the class was dismissed.

In short, the education system of the former Soviet Union is said to have resembled American educational practices of pre-1960 (Irwin, 1991). Teaching methodologies commonly used in many U.S. classrooms, such as cooperative learning and higher level questioning, are only now beginning to be introduced into Soviet classrooms, as education reforms slowly take place.

\section{ACCULTURATION}

All immigrants and refugees relocating to a new culture go through a process of adjustment and acculturation. This process, according to Linton ( as cited in McLaughlin, 1987), generally involves a modification in attitudes, knowledge, and behavior by the immigrant or refugee. The overall process of acculturation demands both social and psychological adaptation, which require the addition of new elements to a newcomer's background, and the reorganization of others.

For Soviet Evangelical refugees, transplantation to America and the subsequent process of acculturation can be especially difficult "due to the extreme differences between old and new social systems" (Belozersky, 1989, p.1). The children of refugees, such as Soviet Evangelical children, experience many of the same emotional stresses as their parents, along with additional stress caused by not having a say in their parents' 
decision to emigrate and by confronting a new language and school system. The lack of friends in the new culture also increases a child's level of frustration and stress (Zevereff A., 1992).

The stages of acculturation and the culture shock that accompanies it are well documented (Belozersky, 1989; Brown, 1987; Handelman, 1983). The four successive stages include an initial sense of euphoria and idealization of the host culture followed by a period of disillusionment when the newcomer discovers that life in America is not what he/she expected or hoped. This period typically occurs after three to six months in the new culture, and may last from six to eighteen months. This time of "culture shock" is characterized by feelings of disorientation, confusion, anger, anxiety, depression, and withdrawal (Belozersky, 1989; New Soviet refugee, 1990; Zvereff, A., 1992). Berry (1988) refers to these components of culture shock as "acculturation stress" (p.48), which has its source in the acculturation process itself. He adds feelings of marginality and alienation and identity confusion to the aforementioned list of culture shock characteristics. The third stage of "culture stress" is marked by a gradual and tentative recovery from the culture shock. The newcomer is beginning to accept some of the differences of the new culture. The full cycle of acculturation is reached when the immigrant or refugee, having developed a more realistic understanding of the new culture, has achieved near or full acculturation, and confidence in the "new" person that has emerged (Brown, 1987).

Boekestijn's (1988), discussion of acculturation focuses on the newcomer's dilemma of identity maintenance versus cultural adaptation. Migration success, according to 
Boekestijn, depends on the learning of meanings and skills and the feeling of being accepted within the host culture. The personal relationships the immigrant forms, either with other newcomers or persons from the host culture, are seen as being critical to developing a feeling of acceptance.

\section{Special Acculturation Problems of Soviet Evangelicals}

Belozersky (1989), documents several common cultural adjustment problems of Soviet emigres, reflecting their psychocultural background. These include unrealistic expectations or an idealized view of the U.S., derived from Soviet propaganda and reports from friends and relatives already living in the U.S. There is often a sense of entitlement or the expectation that the emigres' special status as victims of religious persecution will continue once they have arrived in the U.S. A loss of the sense of security is common, as the Soviet state provided for the basic needs of its citizens, such as housing and medicine. Social workers report their Soviet Evangelical clients becoming increasingly anxious, confused, and tense as they begin to confront the daily basics of American life. For Soviet Evangelical high school students, confronting the daily basics of everyday school life can trigger the same emotions.

Other adjustment problems Belozersky cites include overdependency and manipulative behavior. The Soviet system encouraged obedience and dependency and discouraged autonomy and independence. This creates overdependent behavior on the part of Soviet refugees toward people working with them. Manipulative behavior, learned through constantly being at the mercy of bureaucrats in the former Soviet Union, along with a difficulty in establishing trust and reliance, also learned from 
bureaucratic dealings, are the final adjustment problems.

In Roberts' (1991) study of the resettlement and acculturation of Soviet Evangelical refugees in Oregon, she examined the relationship between socio-cultural settings during their resettlement and their control beliefs. Using a locus of control construct to study the Evangelicals' life experiences in order to predict their acculturation potential, Roberts discovered a high life satisfaction among them. This satisfaction was attributed to strong religious beliefs and a church-centered lifestyle. In spite of this high life satisfaction, Roberts predicts that "acculturation will be slow because of extreme cultural and social differences" (p.33). She refers to these two factors as "a major stumbling block for Evangelical refugees trying to acculturate to the United States" (p.37).

The review of the literature highlights Soviet Evangelical culture, religious beliefs and educational background, but demonstrates the limited nature of available information about Soviet Evangelicals. It particularly exemplifies the scant information available regarding Soviet Evangelical youth. This underscores the assertion put forth in Chapter I that more information regarding both Soviet Evangelical culture and Soviet Evangelical youth are needed. 


\section{CHAPTER III}

\section{RESEARCH DESIGN AND DATA COLLECTION PROCEDURES}

The purpose of this study was to record the educational and cultural experiences of adolescent Soviet Evangelical high school students currently enrolled in ESL classes. The goals of the study were to detail, in the students' own words, their experience of transitioning from the totalitarian, collectivist oriented Soviet culture and school systems to the more open, individualistic American ones, and to create a cultural and educational study of Soviet Evangelical high school students. The study would then serve as a frame of reference for ESL teachers and other school personnel working with Soviet Evangelical high school students.

This chapter is divided into three sections. The first section describes the time frame, research site, and participants. The second section outlines the data collection procedures. The final section details the limitations of the study.

\section{RESEARCH DESIGN}

\section{Time Frame}

This study was conducted over a period of one semester, twelve weeks in length. This time frame allowed for an adequate amount of continual classroom observation, as well as sufficient time for participant interviews. 


\section{Research Site}

(The research site and all participants have been given pseudonyms to ensure confidentiality.)

The research took place at a large, suburban high school in the Portland-Vancouver area, henceforth referred to as Devin High School (DHS). DHS was selected as the research site because of the school's experience in confronting a rapid and unexpectedly large influx of Soviet Evangelical students from 1988-1992. DHS' experience could be seen as typical of other Portland-Vancouver high school ESL programs.

A second reason for the site selection was based on the researcher's established relationship with DHS, through prior employment with the ESL program. This relationship was seen as advantageous to the study for several reasons. The researcher was already familiar with the school, its ESL staff, and many of the Soviet Evangelical students currently in attendance. Since an earlier relationship existed between the researcher and some of the Soviet Evangelical participants, the need to develop and gain the students' trust, culturally important to Soviet Evangelicals and to successful interviewing, was eliminated.

Permission to conduct the study was easily obtained through the researcher's contacts at DHS. Mrs. Benko, the ESL teacher, agreed to participate after hearing an explanation of the study from the researcher. She. in turn, secured verbal permission from the school district's ESL supervisor, and from the school's principal by means of a letter explaining the purpose of the study (see Appendix A, letter of purpose).

The ESL program at DHS has undergone several structural changes in the past four 
years as a result of a rapid increase in Soviet Evangelical enrollment. Prior to 1988, before any Soviet Evangelical students were enrolled, the school district's ESL program was a half day program, five days a week, located at a junior high school. The schedule consisted of one period each of language arts, reading, and Pacific Northwest History and Geography. Beginning and intermediate students were together in each of the classes, and students were bused to the site from the district's two high schools.

In 1990, enrollment had increased from an average of 18 students, primarily Asian, to 33 students, approximately fifty percent Soviet Evangelical. The decision was made by the school district in September 1991 to relocate the ESL classes to DHS, since they had outgrown the portable classroom the ESL program was previously housed in. By the end of the 1991-1992 school year, enrollment peaked at 38 students, with all but three of the eleven new students that year being Soviet Evangelical.

To alleviate the overcrowded classroom, the school district and DHS again restructured the ESL program. It was expanded from a half day to a full day and moved into a much larger classroom. Separate classes were scheduled for the beginning and intermediate levels. Currently, DHS has six ESL classes divided into two levels, beginning and intermediate. All are taught by one ESL teacher, who is assisted by a classroom aide. The daily schedule consists of: 1) intermediate language arts, 2) intermediate reading, 3) teacher's planning period, 4) intermediate U.S. history. 5) beginning language arts, 6) beginning reading, 7) beginning Pacific Northwest geography. The language arts and reading classes are usually taught as a two-hour block period. Each class is 55 minutes in length. 
At the beginning level the students have little or no English skills and are classified as Non-English Proficient (NEP). At the intermediate level students can understand simple English conversation, have a limited vocabulary, and are familiar with the present, past, and future tenses. These students are categorized as Limited English Proficient (LEP). New students are supposed to be tested upon arrival, but this is rarely possible. New students often arrive unexpectedly and without warning. The ESL teacher conducts an informal, on-the-spot test by asking simple wh- questions such as, "What is your name?" "Where are you from?", "How long have you lived in the U.S.?". If the student can answer these questions, he/she is placed in the LEP group. If unable to answer, he/she joins the NEP section. More formal testing is administered shortly after the new student's arrival when time allows.

DHS uses a curriculum designed by the ESL teacher. Since there are no state guidelines for ESL curriculum, the teacher is free to select her own textbooks and set her own proficiency standards for each class and level. However, Mrs. Benko does have to follow the school's graduation requirements. Since U.S. History and Pacific Northwest Geography count towards graduation, Mrs. Benko is required to teach the same competencies as a non-ESL course, using simplified teaching materials. All ESL students are regularly tested. Students progress onto the next level either when they complete the textbook used in the language arts class or when the teacher judges the student's ability to be sufficient to do so. Students exit the ESL program upon completion of the three-series language arts text or if the teacher thinks the student is ready to enter non-ESL classes full time. 


\section{Research Participants}

Three groups of subjects participated in this study: Nine high school age Soviet Evangelical students; four DHS personnel--including the ESL teacher, ESL classroom aide, school counselor, and vice principal; and two people familiar with Soviet culture and education.

The nine Soviet Evangelical students interviewed were selected based on their willingness to participate in the study and because each had spent at least one year living in the U.S. and attending an American high school. Five participants were male and four were female. Two came from Ukraine, two from Siberia, and the others were from Russia. Two students were Baptists, while the rest were Pentecostals. All nine were juniors and seniors in the same intermediate ESL classes and also had some non-ESL classes together. Ages ranged from sixteen to twenty years. Since the researcher was not a speaker of Russian and the cost of an interpreter was prohibitive, students were required to have an intermediate level of English speaking ability. A brief profile of each student follows the Research Participants section.

The high school personnel were chosen for participation based on their close work with Soviet Evangelical students. All had ten years or more experience in secondary education, but had worked with Soviet Evangelicals only since 1989.

Local residents from the former Soviet Union and Americans with knowledge of Soviet culture were interviewed to gain additional insight on Soviet culture, education, and Soviet Evangelicals as a minority group in the former Soviet Union. The Soviet informants were not affiliated with the Evangelical faith, in order to obtain an outside 
perspective of the cultural group being studied for this thesis.

The following vignettes provide a brief biographical sketch of the nine Soviet Evangelical students who participated in this study. Names and any other identifying details have been changed to assure anonymity.

Alex. Seventeen-year-old Alex was the oldest of five brothers. A Baptist, he came to the U.S. at age 15 from Vinnitza, Ukraine. He completed his general education there and at the time of this study was a junior training to be an auto mechanic through the school district's vocational-technical skills center. Alex was described by his ESL teacher as a capable student, but he was sometimes moody in class and often clashed with her.

Julia. Julia was also seventeen years old and a junior. Of the nine students interviewed, Julia was the most assimilated and the most fluent in English. A Pentecostal, she was originally from Anzhero, Sudzhensk, in Siberia, and lived in Los Angeles and Sacramento before coming to the Northwest. Initially homesick for her friends in Siberia, at the time of the study she felt "comfortable" after living in the U.S. for five years and believed that she was "becoming an American".

Nick. Nick was Julia's younger brother and the youngest of thirteen children. He was sixteen years old and in the tenth grade. Like his older sister, he had achieved a high level of speaking proficiency and felt quite at home in the U.S. In the ESL class he was known for his friendly demeanor and wit. He was quick to make everyone laugh, including the teacher, with his humorous comments during a lesson.

Maria and Olga. Maria and Olga were sisters from Kiev, in Ukraine. Both were 
in the same ESL classes and are constant companions. Maria, sixteen, was one year older than Olga. Both were deeply religious and closely followed the style of dress and behaviors dictated by their Pentecostal faith. They also took great pride in being Ukrainian. Maria was the most talkative of the students interviewed and described herself and her culture in a humorous, self-deprecating manner. Olga was less sure of her English ability. The sisters were active in the school's horticulture program and worked in the school's florist shop.

Peter. Peter, age eighteen, was a junior. He had been in ESL for almost three years and felt he was ready to exit the program, although his teacher disagreed. He had been in the US since 1991, coming directly to the Northwest from Zheleznovodsk, Russia, with his fifteen-member Pentecostal family. Peter said he was now bored with school, although he liked it one year ago. It was common for Peter to work in spurts, one moment applying himself to his classwork, and the next moment sleeping or reading a magazine.

Ven. Ven, age sixteen, was the youngest of eight children and came from Volgograd, Russia. A junior, he was following an older brother and sister respected and known for their studiousness and academic achievement. While a capable student himself, Ven had often been a discipline problem in class and was finally separated from his peers by the ESL teacher in an effort to keep him focused on his classwork and to improve his low grades.

Dimitri. Dimitri, a Baptist, was sixteen years old and in tenth grade. He and his family of nine emigrated from Frunze, Russia, and first lived in Tennessee, a place he 
preferred to where he was living now because, "I liked it better. I had a lot of fun and friends." He has had periods of homesickness and has expressed a desire to go home to Russia. Dimitri had previously been suspended from school and was often disruptive in ESL class. Off-task behaviors such as talking and refusing to do class work were near daily problems. His other teachers, such as his art instructor, reported, however, that they did not experience these same problems.

Yelena. At age 20, Yelena was the oldest student in the class. She was a senior and a Pentecostal. Yelena completed her general education studies in Kazakstan and then attended one year of music school before coming to the U.S. in 1990. She studied piano for seven years and enjoyed it immensely. In class, Yelena's age and her serious demeanor set her apart from her Soviet Evangelical peers. She disliked the classroom behavior of the other Soviet Evangelical students, commenting, "They are like animals let out of the zoo."

\section{DATA COLLECTION PROCEDURES}

Data for this study were collected through three methods: 1) classroom observations, 2) a language learning preference survey, and 3) interviews. Open-ended interviews with guiding questions were the primary source of data, while the survey and classroom observations served as secondary sources of information and as topics for discussion during the interviews (see Appendix D: Interview Guiding Questions).

\section{Classroom Observation}

During the first two weeks of the six-week observation period, observations were limited to recording the general classroom activity (See Appendix B, sample 
observation coding sheet). This was done in order to gain an overview of the classroom and its daily routines, procedures, student-to-student interactions, and teacher-to-student interactions.

After the two-week period the focus of observations shifted to the Soviet Evangelical students. Classroom behaviors, especially those most often cited by ESL teachers as being problematic, such as cheating, talking at inappropriate times, showing disrespect for authority, and being continually unprepared for class, were documented along with the teacher response. These observations were often used as points of discussion during student interviews.

Observations during the first two weeks were recorded in five-minute increments, using an observation coding system to record teacher-student interactions. When the focus narrowed to Soviet Evangelical behaviors and teacher response, observations were noted only when the behavior occurred.

At first the researcher sat at a table in the back of the classroom due to a lack of empty desks. To compensate for the inadequate viewpoint, which obscured actions taking place in the front half of the classroom, the researcher periodically sat at the teacher's desk located at the front of the classroom, and also walked through the rows of desks. This provided the opportunity for more effective observation of the entire class. Approximately two weeks after classroom observations began, the ESL students from the district's other high school were transferred from DHS to a permanent ESL classroom at their home school. Empty desks then became available, allowing the researcher to sit in various locations and to sit also next to students who shared their 
textbooks and class papers with the researcher.

A total of 37 hours of observations were completed during the six-week

observation period. At first, observations were made for two consecutive class periods, each 55 minutes in length, Monday through Thursday. Later, when the researcher's time became limited, observation days decreased to twice a week, Tuesdays and Thursdays.

\section{Language Learning Preferences Survey}

The purpose of the Language Learning Preferences Survey was to gather more information about the Soviet Evangelicals' preferences and styles when learning a language. As discussed in Chapter II, Soviet schools relied heavily on rote methodology and oral response in the classroom. Current American methodologies such as discussion, communicative approaches, and cooperative learning were not used by Soviet teachers. These methodologies have been identified as difficult for Soviet Evangelical students to adjust to. Therefore, a survey was administered to determine what, if any learning preferences existed among the students. The survey used was the same one that was used in Wiggins' 1994 study of adult Soviet Evangelical students. It asked students to rank thirty different language learning activities. The questions covered a variety of activities, including group versus individual, in-class versus out-ofclass and communicative versus grammar-translation. The survey was not oriented toward any one cultural group, but could be used cross-culturally. Wiggins obtained the survey from Willing, 1988, in a study of immigrants to Australia (See Appendix C, Language Learning Preference Survey).

The survey was administered during class with the ESL teacher present. To avoid 
the potential problem of the non-Soviet students feeling left out, all students completed the survey. The survey was not translated due to the impossibility of providing translations for the more than five different languages spoken by the students. Before completing the survey, the researcher explained its purpose and any words or statements that were difficult to understand to the class. Students were also shown how to circle their responses. Students were told they were not required to give their name, so as to ensure anonymity, and that the survey was not 'a test', so their answers would be neither right nor wrong, but simply reflect their opinions.

The results were tabulated according to nationality. Only the results of the Soviet Evangelical students are included in this study.

\section{Interviews}

Interviews formed the core of this study. Since a primary goal of the study was to detail, through the Soviet Evangelical students' own words, their experiences, interviewing was the best research technique to achieve this goal. In order to answer the questions around which this study is framed, interviewing also provided the most effective research tool.

Open-ended interviews with guiding questions based on ethnographic interviewing techniques were used (See Appendix D, interview guiding questions). In addition to the interviews with the nine Soviet Evangelical participants, interviews with the ESL teacher, classroom aide. school counselor, and vice-principal were conducted in order to gain insight into the Soviet Evangelical students' adjustment process to the U.S. classroom, behaviors, and the school's approach to confronting a new and unknown 
student population. Many informal talks also took place during the fifteen-minute break period with both students and the ESL teacher.

Interviews were held at the high school during the two- hour intermediate ESL language arts and reading block, either in the cafeteria or in the library. Finding a suitable location was a problem that was never satisfactorily resolved. There were no empty classrooms or offices available, and the small office adjoining the ESL classroom was used for individual or small group work. The library and cafeteria were the only remaining options. The library was used if free of other classes, since the interviewing could disturb the other students' work and vice-versa. The cafeteria was a large, cavernous like room with poor acoustics that made it difficult to hear even a normal face-to-face conversation. Additionally, students passing through and the custodians preparing for lunch were noisy distractions. However, it was often the only site where an interview could take place.

Prior to the interviews, the ESL teacher and the researcher selected nine intermediate level Soviet Evangelical students for participation, who were then asked by the researcher to participate in the study. Interview questions were formed with input from both the ESL teacher and classroom aide. The questions were tested on the first two interviewees, and necessary changes were made.

The nine participants were given informed consent forms for their parents and them to sign one week before their scheduled interview. Two of the students were of legal age, so no parental permission was required. The researcher explained to each student the purpose of the study and the reason for the student's participation. The 
researcher and the participant together read the permission slip. Difficult vocabulary was explained by the researcher. Students were also told they did not have to agree to be interviewed if they did not wish. None of the nine refused to participate.

Each interview began with a brief review by the researcher of the study's purpose and the reason for the student's participation. Students were asked to select a Russian pseudonym, in order to protect their identity. This served to break the ice in a humorous way. None of the students had ever considered changing their names and were amused by the lengths to which confidentiality was maintained. Personal data about the student including age, grade, religious affiliation, family size, and previous English study were collected next.

The interview then progressed to the guiding questions. The purpose of using guiding questions was to assure that each interview covered the same topics and was structured similarly. However, it was flexible enough to allow for extended conversation on a particular topic.

Students were usually hesitant at first to speak at length. Questions were often answered with a simple 'yes' or 'no', or one or two short sentences. It was necessary to ask students to 'tell more' or 'give an example' in order to elicit more information. The problem of hesitancy was somewhat solved by interviewing two or more students at a time or allowing friends who happened to wander by to join in.

Individual interviews lasted approximately two hours divided over two days and two class periods, each 55 minutes in duration. Interviews rarely lasted two consecutive periods because students became fatigued and therefore less verbal. Two-hour blocks 
also did not allow the researcher time to review notes and prepare new or follow-up questions for the second session.

Data were recorded in notes, which were later analyzed for common themes and issues. These were pursued in follow-up interviews. A tape recorder was not used since in initial interviews it caused students to feel nervous. The poor acoustics and noise in the cafeteria also made transcribing the interviews difficult. A tape recorder was used only for the interviews with the vice-principal and counselor, since their interviews were held in the privacy of their offices.

\section{LIMITATIONS OF THE STUDY}

Wiggins (1994) cites three limitations of her study of Soviet Evangelical aduit ESL learners: time restrictions, language barrier, and her lack of training in observational analysis techniques. These three areas are also limitations of this study, along with the researcher's lack of training and experience in ethnographic interviewing.

Time restrictions were more of a difficulty for the Soviet Evangelical students and school personnel than for the researcher. Since the interviews were conducted at the high school during the school day, interviewing interrupted both the students' and the staff's workday. Conducting the interviews after school hours would have allowed for longer interviews that did not interrupt class periods or work time. This was possible with only two of the participants.

The language barrier between the researcher and the Soviet Evangelical participants was the second limitation. Although intermediate level students were selected for this study, some being fairly fluent in English, language problems did 
occur. Comprehension of the researcher's interview questions and the students' difficulty in communicating their answers, usually due to a lack of vocabulary. were the two biggest language problems. Conducting interviews in the students' native language or using an interpreter would improve this situation.

The final limitation of the study was the researcher's own lack of training and experience in ethnographic interviewing techniques and writing style, including adding thick descriptions and refraining from adding the researcher's own value judgements to the text. 


\section{CHAPTER IV}

\section{EXPECTATIONS AND INITIAL IMPRESSIONS}

Chapters IV, V, and VI answer the main question posed in this study, "Who are Soviet Evangelical high school students? This question is partially answered in Chapter II, which describes Soviet Evangelical religious and cultural characteristics. A brief outline of the education system in the former Soviet Union is included in the chapter to understand more fully the background of these students. Chapter IV focuses on the study's first guiding question, "What expectations and impressions of American culture and education system do Soviet Evangelical high school students have?" The students' knowledge and initial impressions of the U.S., along with their perceptions of their new American high school are detailed. The differences the students see between Soviet and U.S. schools are also included.

Chapter $\mathrm{V}$ addresses guiding question number two, "What educational background do Soviet Evangelical students bring to the U.S.?" The students' preferred language learning styles and attitudes towards education and their ESL class are discussed. Classroom behaviors characteristic of Soviet Evangelical students are also discussed.

The final guiding question, "How do the above factors affect their adjustment and acculturation to American schools and culture after students have resided for one year or more in the U.S.?" is examined in Chapter VI. 


\section{AMERICAN CULTURE}

\section{Emigrating to the U.S.-- Great Expectations}

Many immigrants and refugees to the U.S. bring with them high and often unrealistic expectations of life in America. If these expectations are not met, disappointment and culture shock may follow. The nine Soviet Evangelical participants were no exception. "Happy" was the word the majority of students used to describe how they felt when told by their parents they were finally going to emigrate to the U.S. Emigrating was not a surprise, since it was a decision their parents often took a year or more to make, and was the goal of many Evangelical families. As Maria said, "Everyone wants to come to America." The wait of up to two years for an exit visa only served to heighten the anticipation of leaving.

Most students, after hearing about America from friends and family already there, had high expectations of new opportunities in the U.S. These opportunities included travel and the chance to live in a more prosperous or "better" country. As Ven relates:

I was really happy because it was a different country and I had never been before. I started thinking about some pictures of America and how my life in the U.S. will be like them.

Some students looked forward not only to a new life, but also to the chance to pursue personal interests. Alex, a car enthusiast, said, "I knew the U.S. was one of the best countries in the world. There were more opportunities and good cars." Others, like Nick, felt that coming to the U.S. was good simply because "People were always saying good things about it [America]."

Only two students mentioned religion as the primary motivation for their family's 
Only two students mentioned religion as the primary motivation for their family's move to the U.S. Maria and Olga, the two deeply religious sisters, felt happy about emigrating because "God told us to go. Some people are supposed to go to the U.S." For them, emigration meant the fulfillment of God's word.

The excitement of coming to the U.S. was tempered by feelings of sadness at leaving friends and family behind, and fear of what might lie ahead for them in a new country. Most, like Julia, worried about the possibility of never seeing their friends again. For all students this was the most difficult part of emigrating. Students had also heard of or read about negative aspects of American life, such as high crime and homelessness. This left some a little fearful. Nick, for example, believed "all Americans carried guns in their cars. If a person didn't drive when the light turned green, another driver would shoot them." All problems, such as this, were solved with guns, he thought. Nick and other students spoke of quickly finding out that these and other stereotypes were false. For Olga and Maria, however, initial feelings of sadness and fear were diminished by "faith that God would protect us in America."

Only two students spoke of not wanting to go to the U.S. Peter remembered arguing with his mother, telling her, "I want to stay. It will not help me to go to America." Dimitri wanted to remain in Russia in order to be with his grandfather, with whom he had a close relationship. "I had lots of friends and I didn't want to leave them," he added. Both, like many adolescent immigrants, had no choice regarding their parents' decision to move to the U.S. and reluctantly came with their families. 


\section{EDUCATION}

\section{School in the U.S.- Initial Impressions}

The first day of school in the U.S. left all but one student feeling lost and homesick. The new surroundings, a different school system and language, and a lack of friends led to these feelings. Typical responses to the question, "Describe your first day in an American school," included Yelena's answer:

I felt lost and I was very quiet. I felt very tired after school from sitting and trying to understand everything. I wasn't comfortable.

Ven remembered, "All the students stared at me. They asked me many questions I didn't understand." "I felt lost," said Dimitri. "It was such a big change. I felt really bad and I wanted to go home to Russia."

Julia quietly described the sadness and fear she felt because she did not speak English and was the only Russian student at her new school:

I was scared. I didn't speak any English. I felt so sad. There were no Russians. I felt so homesick.

The students remembered seeing many new and different things. Maria, Olga, and Julia all expressed surprise to see African-American students. Julia had never seen an African-American before, and remembered how difficult it was for her not to stare. For Maria and Olga, Africans or Blacks were "rare in Ukraine" and they found it strange to be attending school with them.

Yelena spoke of seeing American students in the cafeteria and thinking to herself, "They all look strange." She found it strange that most American teachers helped their students, since this was not always the case in her Soviet experience. It was not 
something she expected to encounter at her new U.S. school. Yelena disapprovingly spoke of "seeing students arguing with teachers or boyfriends and girlfriends kissing each other." These two behaviors she observed her first day of school bothered her and continued to do so at the time of this interview.

Some of the students' initial impressions left them with negative misconceptions about their new school. Ven, for example, initially assumed his new teacher to be unfriendly and uncaring. This was based on the manner in which the teacher started class:

He didn't say "good morning." He just started the class. I thought that was strange. Russian teachers always say good morning. Because he didn't say it, I thought he was mean. Later, I thought he was nice man.

The adjustment period to their new American schools varied for all the participants. Their estimates ranged from one week to one year. All credited their ESL teachers with providing the greatest help during this time. Nick remembered how his ESL teacher made him feel immediately welcome on his first day of school. "She knowed [introduced] me to all the students," he recalled. This introduction make him feel more at ease and also allowed him to quickly become acquainted with his mostly Mexican classmates.

Sometimes other ESL staff or students helped the newcomers. Julia, the only Russian girl in her school. met a Rumanian student who spoke some Russian and tried to help orient Julia to her new school. Julia remembered feeling "very happy" to have the Rumanian girl's help at that time. A Russian-speaking ESL staff assistant came to Olga and Maria's class. This, they felt, was a big help, since they had many questions 
about their new school, and now had someone to answer all of them in their native tongue.

Sometimes it was just time that helped a student to adjust to the new environment, as was the case with Dimitri and his new junior high school in Tennessee:

I felt lost because big change. There was not really ESL class because not a lot of immigrants. I felt bad. I really wanted to go back to Russia. Teachers and students were nice. Two or three months later I feel okay.

Six months later Dimitri moved from Tennessee to the Portland-Vancouver area. This time some of his new American classmates made him feel unwelcome:

There were lots of Russian people in this school. American people say something bad and Russian people beat them up. They [the Americans] say, "Why don't you go back to your own country?" I say them, "Why do you say that? You're a guest here too. You're not Native American." The Americans just cuss back.

The only student who claimed not to have felt homesick or lost on his first day of school was Alex. Unlike the other participants, he purported to have taken delight in his new school:

I was just like a child. Everything was interesting and different. I looked at everything with my eyes wide open. I was happy. Everything was fine.

\section{Differences Between U.S. and Soviet Secondary Schools}

The students cited several differences between U.S. and Soviet schools, the first being the conduct of the American teachers. All were surprised and impressed by the friendliness of their new American instructors. Friendly to the Soviet Evangelical students meant that the American teachers did not strike them or belittle them in class for their religious beliefs. "Teachers are mean in Russia. They hit kids," was how Julia described this difference. Her brother, Nick, added, "American teachers are nice. They 
act like your friend. In Russia a teacher yells at you when you are being a bad boy." Peter remembered the big ruler his Soviet teacher had. "He hit students everywhere if you don't listen," he said. He admitted to receiving a few blows himself.

Another major difference between Soviet and U.S. high schools concerned the organization of the school. This included changing teachers and classmates, school rules and regulations, and physical space. All were bothersome to the Soviet Evangelical students and made them homesick for their former schools.

Alex commented on the changing of instructor, room, and classmates after each class period. In Soviet schools, he explained, a group of students will stay together as one class from grades four through eleven. A teacher is assigned to that class and becomes the equivalent of a homeroom teacher. For Alex, the Soviet system was "cool." "It's like one family. You know them [the classmates] like brother and sister," he said. The constant changing of teachers and classmates and moving from room to room seemed impersonal to him and made the atmosphere in the American school uncomfortable. Alex felt it also made it difficult for him to get to know his American classmates.

School rules and regulations also differed in the two school systems. All the students spoke of the difficulty in adjusting to and remembering the myriad of requirements and procedures students had to follow, for everything from graduation to simply leaving class to use the restroom.

Two students, Alex and Dimitri, were most bothered by the difference in rules and regulations. They spoke at length of their annoyance with this. Both cited as an example the procedure for absences. According to school policy, upon returning to 
school from an absence, a student must go to the attendance office, present a written excuse from his/her parent, and obtain an admit, or slip of paper for each of the student's teachers to sign. The absence is noted on the admit slip as being excused or unexcused. This procedure of accounting for absences seemed excessive to both students. As Alex described it:

In the USSR you can have absences. If you want to be home you can. You can go to school but it doesn't matter if it [the absence] is excused or unexcused. You can make up the work by yourself. Of course the teacher asks about the absence, but it doesn't matter. You just do the work. School is your decision.

For Dimitri, school attendance was something he claimed to

have negotiated with his instructor:

In Russia they [the school authorities] don't make you go to school. It's your decision. The teachers don't really care. They don't call your parents. There are admit slips. In Russia you can make a deal with the teacher. Do something for him and get a better grade. It happened a lot.

While the above instances might sound like the bravado of a student who is proud to have beaten the school system, it does, in a sense, reflect a difference in organization between U.S. and Soviet schools. In the Soviet system, all studies are done during the school year in preparation for end-of-the year final exams. Grades and promotion to the next level are based on the results of these exams. This is in contrast to the U.S. system, where in many high schools, such as Devin, grades are issued quarterly, or every six weeks. Therefore, a student is required to have all work completed before the end of a quarter. Additionally, Devin requires work missed due to absences to be made up as soon as the student returns to school. Time equal to the number of days absent is given to complete the missed work. This system was new to the Soviet Evangelical students 
and both the ESL teacher and classroom aide spoke with frustration of getting Soviet Evangelical students to complete and hand in missed classroom assignments and comply with the system of admits.

For older students such as Alex, who came to the U.S. after having already completed General Education and possessing a diploma proving so, Devin's credit system was another source of contention. Alex spoke angrily of not receiving upon enrollment any credit from the DHS guidance counselor for his studies in Russia. As a result, he was enrolled as a freshman, thus beginning high school all over again. "I don't understand the system," he said. "I bring a diploma and the counselor didn't give me anything for it."

Three girls, Maria, Olga, and Julia, brought up the subject of the differences in physical appearance between Soviet and American high schools. Julia and Maria found American high schools to be "disordered". By disordered the two meant that DHS looked dirty with things cluttered everywhere. Olga preferred Soviet schools, which were "clean and ordered" in her opinion. She animatedly described clean classrooms decorated with curtains and plants and two person desks in straight rows. "Each class decorate their room and make it pretty. Here it is ugly." For Olga, a clean, orderly, and decorated classroom was a "happy" place to be. Cleaning and decorating the classroom with her classmates was an activity she looked forward to at the beginning of each new school year. She was disappointed there was not this tradition at DHS. Maria's sister Olga nodded in agreement.

Julia added that the structural layout of DHS was confusing to her. Classrooms and 
hallways seemed to be everywhere, in a chaotic design. She said she still would occasionally get lost at DHS, even though she had been there for a year.

Finally, all nine of the Soviet Evangelical students commented on the difference in the amount of homework between U.S. and Soviet high schools. Nearly all were pleased that American high schools generally required less homework than their Soviet schools. Less homework and in-class work, however, led the students to characterize American high schools as being less rigorous than the ones in their country. Peter believed this made Soviet schools superior to American ones:

I learned more. Russian students work harder than Americans, especially in algebra and geometry. There was lots more homework, so I learned more.

Ironically, Peter often did not complete his homework or in-class work.

Only one student, Yelena, noted a difference in orientation or approach towards learning between Soviet and U.S schools. When asked how she was able to succeed in and successfully adjust to such a new and different environment, she replied:

I don't know why I'm okay. Here American teacher says if you don't want to study that's your problem. In Russian teacher goes to your home to have conference and talk to parents. Here you take care of yourself.

Yelena had recognized the American value of taking responsibility for one's own actions, in this case learning. This realization enabled Yelena to get along well in the U.S. classroom, which in turn accounted for her academic success. This was confirmed by her ESL teacher, who praised Yelena's ability to work independently and who appreciated the way Yelena quietly did her classwork, completed assignments on time, and inquired about make-up work after an absence. The other Soviet Evangelical 
students did not do these things, for which Yelena had harsh words:

It is their own problems. They do not care. I feel bad for Mrs. Benko. They make problems for her. I do not like them.

This chapter has discussed the responses to the study's first guiding question, "What expectations and understanding of American culture and education system do Soviet Evangelical high school students have?"

The initial excitement and anticipation the nine Soviet Evangelical students experienced upon coming to the U.S. changed into loneliness, frustration, and homesickness once they began attending their new U.S. high schools. The challenge of confronting a new language along with a new school system proved to be a difficult one, especially at first. For most students, time and their ESL teachers helped them adjust to and learn about their new environment. The students felt they were able to adapt in periods ranging from one week to one year. However, this sense of having adjusted to the U.S. classroom did not necessarily give these students a feeling of contentment. Practices common in their former schools were missed, and there was a high level of frustration among some students with the new regulations to follow, especially school attendance policies and the credit system. Only one student had successfully adapted to the new educational environment and acquired the skills needed to excel in the U.S. classroom. 


\section{CHAPTER V}

\section{ORIENTATION TOWARD LEARNING}

After focusing in Chapter IV on the participants' impressions of their new country

and the differences they perceive between Soviet and American high schools, Chapter V addresses research question two: "What cultural and educational values and experiences do Soviet Evangelical high school students bring to the U.S.?" Prefered learning styles, attitudes toward the classroom and the teacher, and the influence these factors play in shaping the students' orientation toward learning and classroom behaviors are examined.

The results of the language learning survey are presented in order to show how Soviet Evangelical students prefer to learn. Next, the participants discuss their experiences in the ESL classroom, along with their attitudes and opinions toward ESL in general. Finally, classroom behaviors are addressed. The students discuss behaviors which have been cited by their ESL teachers as being problematic. The survey results, ESL experience, and classroom behaviors are related to the participants' cultural and educational backgrounds to show how they influence their orientation to education.

\section{LANGUAGE LEARNING PREFERENCE SURVEY}

It was noted in Chapter II that the U.S. and Soviet education systems differ in their modes of learning. The system of the former Soviet Union featured an authoritative, 
highly-structured, uniform approach which relied heavily on rote memorization, oral response, and a teacher-fronted classroom. In contrast, the U.S. approach is generally thought of as emphasizing the development of critical thinking skills, inductive reasoning, and communicative competence through activities such as role play and cooperative group work.

How a student prefers to learn is influenced by both cultural and individual factors. While a culture may stress one approach to learning, such as rote memorization in the Soviet school system, it cannot be assumed that all students of that culture prefer to learn, or learn best, in that way. The student's individual preferences also affect learning styles.

The results of the survey entitled "How Do You Like to Learn Best?" showed varied preferences among the participants toward thirty different language learning activities and techniques (see Table 1: Language Learning Preference Survey). The survey questions ranged from group to individual work and in-class versus at-home study. Students selected one of four possible responses consisting of "no", "a little", "good", and "best". A numerical value of one to four was assigned to each response, with one being the lowest and four the highest. The average response to each question was then calculated.

The following English language learning techniques received the highest rankings, ranging from 3.6 to 2.75 on a 4-point scale, with 4 the most favored preference. Listed in order from highest to lowest, they included: Learning many new words, the teacher explaining everything to the class, talking to friends in English, learning by pictures, 
TABLE 2: LANGUAGE LEARNING PREFERENCE SURVEY

\begin{tabular}{|c|c|}
\hline \multicolumn{2}{|l|}{ HOW DO YOU LIKE TO LEARN BEST? } \\
\hline QUESTION & RANKING \\
\hline 1. I like to learn many new words. & 3.6 \\
\hline 2. I like the teacher to explain everything to me. & 3.5 \\
\hline 3. I like to learn by talking to friends in English. & 3.5 \\
\hline 4. I like to leam by pictures. films, videos. & 3.5 \\
\hline 5. I like to learn by games. & 3.3 \\
\hline 6. I like the teacher to tell me all my mistakes. & 3.25 \\
\hline 7. I like the teacher to let me find my mistakes. & 3.13 \\
\hline 8. I like to leam English words by hearing them. & 3 \\
\hline 9. I like to learn English words by doing something. & 3 \\
\hline 10. I like the teacher to give us problems to work on. & 3 \\
\hline 11. I like to leam English by talking in pairs. & 2.9 \\
\hline 12. At home, I like to learn by watching TV in English. & 2.9 \\
\hline 13. I like to study grammar. & 2.9 \\
\hline 14. I like to learn English words by seeing them. & 2.75 \\
\hline 15. 1 like to learn English in small groups. & 2.75 \\
\hline 16. I like the teacher to heip me talk about my interests. & 2.5 \\
\hline 17. I like to practice the sounds and pronunciation. & 2.5 \\
\hline 18. 1 like to learn by watching/listening to Americans. & 2.4 \\
\hline 19. I like to go out with the class and practice English. & 2.3 \\
\hline 20. I like to learn by conversation. & 2.13 \\
\hline 21. I like to have my own textbook. & 2.13 \\
\hline 22. I like to learn by using English in stores/buses. etc. & 2 \\
\hline 23. At home. I like to leam by reading newspapers. & 2 \\
\hline 24. 1 like to learm by reading. & 2 \\
\hline 25.1 like to leam English with the whole class. & 2 \\
\hline 26. At home. I like to leam by studying English books. & 1.9 \\
\hline 27. 1 like to listen to and use cassettes. & 1.75 \\
\hline 28. At home. I like to leam by using cassettes. & 1.75 \\
\hline 29. I want to write everything in my notebook. & 1.75 \\
\hline 30. I like to studv English br muself (alone). & 1.5 \\
\hline
\end{tabular}


films and videos, games, the teacher telling students their mistakes, the teacher letting students find their own mistakes, learning English words by hearing them, learning English words by doing something, the teacher giving students problems to work on, working in pairs, watching television at home, studying grammar, learning English words by seeing them, and working in small groups.

Based on these ratings, the students demonstrate characteristics of both 'communicative' and 'authority-oriented learners'. According to Wiggins (1994) 'communicative' learners like to learn, as the name implies, through conversational means, such as talking to friends in English, participating in conversations, using English outside of the classroom, and watching and listening to both native speakers and English-language television. In contrast, 'authority-oriented' learners prefer a more analytical approach. They like to have their own textbooks, to have the teacher explain everything, including their mistakes, and to study grammar. Learning by reading and by seeing new words are also preferred.

Five activities were ranked between 2.5 and 2.3, or between "good" and "a little", indicating an ambivalent attitude by the students towards them. All were communicative activites except the highest ranked one of learning by having the teacher give students problems. The others, in decending order included: the teacher helping students talk about their interests, practicing English sounds and pronunciation, watching and listening to Americans, and going out with the class and practicing English.

Activities and techniques with a low ranking, between 1.75 and 2.13 , or "a little" or 
"no" preference were: learning by conversation, having his/her own notebook, using English in stores/buses/etc., reading newspapers at home, reading newspapers in class, learning English with the whole class, studying English books at home, using cassettes and tapes at home, writing everything down in a notebook, and studying English alone.

As with their choices of preferred techniques, the students showed both a communicative and authority-oriented orientation. The students rejected some communicative activities such as learning through conversation and using English outside of the classroom, but also rejected some authority-oriented ones, including studying alone and writing everything down in a notebook.

In summary, the survey responses of the Soviet Evangelical participants show them to be both communicative and authority-oriented learners. The students appear to show a slight preference for a communicative approach by rating more of these activities favorably and by rejecting a higher number of activities associated with an authority-oriented approach. However, the students gave high ranking to two authorityoriented activities-- having the teacher explain everything to the class and telling students all their mistakes. They also indicated a strong dislike for the commonly used communicative technique of learning through conversation and were indecisive on other often-used communicative activities such as talking about personal interests, watching and listening to Americans, and practicing English outside of the classroom.

\section{THE TEACHER}

As stated in Chapter II, the role of a Soviet teacher was to be a giver or dispenser of knowledge. The teacher was an authoritarian figure whose word was final. Students 
were not allowed to question or challenge this authority. Openly disagreeing with an instructor was also prohibited, as he/she was always assumed to be correct. However, this did not prevent students from privately disagreeing. Wiggins (1994) quotes a Soviet Evangelical man who remembered disagreeing inside, as he called it, with a teacher. This was the only way in which he could do so.

Also noted in Chapter II was the threat Soviet instructors posed to Soviet Evangelicals. As part of the Communist system, some teachers verbally harassed students about their Christian beliefs and tried to persuade them to reject their religion. Teachers, as some participants claimed, would also grade their schoolwork unfairly due to their religious status.

\section{Good and Bad Teachers}

Within any school system there are teachers regarded by students to be good or bad. For Soviet Evangelical students the characteristics that defined good and bad instructors were traits such as personality, approach to discipline, and teaching methodology. The teacher's treatment of students as Evangelicals also figured into their opinions.

Among the nine participants, a good teacher demonstrated the following qualities: a friendly demeanor, a sense of caring for their students, and ensuring, through teaching methodologies, that the class understood a lesson. Julia's description of her two "best" Soviet instructors summarizes the general opinion of all the participants of what constitutes a good Soviet teacher, "They write everything down and make sure everybody understood. They care about students and they show it." Other qualities and actions of Soviet teachers that the participants esteemed were speaking directly to the 
student, instead of addressing concerns and criticism to their parents via a home visit or note written into their notebook, as Maria and Olga noted. For Peter, the self-described "so-so" student, good teachers were those willing to bend the rules a bit, such as in the case of poor grades. "You know," he said. "You get a bad grade but they [the teacher] don't keep it, so you will be O.K."

All the participants cited Soviet instructors who did not verbally harass them or ridicule them in class for their religious beliefs as good teachers. These teachers treated the students just like their non-Christian classmates and ignored their status as Believers. Peter liked one particular Soviet teacher because, "He respected Christians, especially our family." The fact that these teachers did not participate in the routine harassment made them admirable and appreciated by the students.

The antithesis of a good Soviet instructor was provided by Peter:

Teacher doesn't explain things. Yelling everyday at students...Teacher gets mad if you disagree. You will get bad grade.

In short, a poor Soviet teacher, in the participants' opinion, had the universal bad teacher traits of meanness, assigning too much homework, and incompetent teaching skills.

The students also felt bad teachers were often vengeful, failing students in retaliation for challenging him/her in class, or as Maria and Olga claimed, for simply not liking a student. They, along with the other participants, said they had been the victims of this during their Soviet school days.

The two negative traits the participants focused on the most were the attitude toward and treatment of Soviet Evangelicals by their Soviet instructors. All nine participants 
easily recalled teachers who had discriminated against them on the basis of their religious status and remembered incidents of harassment or ridicule in the classroom. Julia remembered as a child in the first grade being bothered almost daily by her teacher who would ask her, "Why do you believe in God? There is no God." She also told of receiving a failing grade from her algebra instructor:

He hated me because I was Christian. He gave me ' $F$ ' even if I did the work. Then he lied about giving ' $F$ '.

Surprisingly, all the students downplayed the bad Soviet teachers, as though they and their actions were just a normal, bothersome part of everyday school life. As evidenced by their initial surprise as to the friendliness of American teachers, these students accepted strict, harsh, unfriendly Soviet teachers as the norm. "It's their job," or "They are only doing what the government tells them to do" was how the students explained or rationalized the teacher's behavior. Peter shared the example of an instructor who became angry with him when he refused to attend a Revolution Day celebration parade with his classmates:

She was very mad. She called Christians bad names. Then [after the parade] she was nice again. She was only doing job. Because every teacher is Communist.

Some Soviet Evangelical students also received support from their non-Christian peers. For example, when one of Yelena's "bad teachers" told her classmates she was an undesirable person because she was a Christian, Yelena said her classmates defended her. They told the teacher that she was a good person and their friend. Faith and parental guidance sustained Maria and Olga. They did not "hate" their former Soviet instructors in accordance with their religious beliefs, which they said, forbid them to 
hate. Additionally, they followed their parents' advice:

Don't be afraid. It's O.K. Be nice to them [the teachers] because Jesus died for us. Say thank-you [when being ridiculed by a teacher].

The acceptance of bad teachers as a normal component of school, religious convictions, and the belief that harassment was part of being a Soviet Evangelical, allowed the students to tolerate their bad Soviet instructors, but also cultivated a deep appreciation for the ones they perceived as good.

\section{ATTITUDES TOWARD EDUCATION AND ESL}

The participants' attitudes towards education in general and their ESL class were split along gender lines. Overall, the four females had a positive orientation towards school and ESL. They enjoyed both and had few, if any, complaints. They rated ESL as one of their favorite classes. In contrast, the four males expressed decidedly negative opinions and a clear disinterest in school. Three, with the exception of Nick, were strongly dissatisfied with the ESL curriculum, their individual progress, and the teacher's methodology.

In spite of the harassment received from some of their Soviet teachers because of their religious status, Yelena, Olga, Julia, and Maria all said they enjoyed their Soviet school days. School was where their friends were and it seemed to be primarily a social activity for them. Olga and Maria, for example, liked school because it was "fun." Fun meant the social aspect of school, such as seeing their friends. Their Soviet view of school has carried over to their American high school, which is also "fun" except for physical education. The sisters described this class as "kind of boring": 
You must always dress-up [change into gym clothes]. In Russia it was fun. Boys like to play basketball but girls just sit and tell stories. Somebody go get ice cream.

Yelena also enjoyed her former Soviet school, not only because of the daily contact with friends, but also because she liked learning and was able to pursue her hobbies of horticulture and music. Although she also enjoys school in the U.S., the struggle to fully comprehend her teachers and materials seems to take away some of the pleasure. She admits to disliking some classes she said she would normally like, such as senior-level social studies, due to the language difficulties.

Because of her facility with both English and Russian, Julia was often sought out by the ESL teacher or other Soviet Evangelical students for help with translations, interpreting, or other tasks. The opportunity to orient new Soviet Evangelical students to DHS and tutor those less proficient in English were the aspects of ESL that Julia most enjoyed. Making friends with students from other cultures was another favorite part. She added that she only made friends with "students who are good to me" or those who did not tease her about her Siberian/Russian nationality.

Maria and Olga enjoyed ESL because they were often given small duties such as collecting and passing out papers. Their favorite activity was journal writing because it allowed them to communicate on a more personal level with Mrs. Benko. Their only complaints about ESL were that there were no games on Fridays or small-group work as in their previous ESL class. When told by the researcher that Mrs. Benko had attempted these activities in the past, but had to discontinue them mainly because the Soviet Evangelical students socialized too much during these times and didn't do their work, 
both were surprised. "She should try again," they suggested. "Maybe it will be different now."

Yelena, like her three peers, also felt positive about ESL. Everything about the class was good, in her opinion, from textbooks and assignments to Mrs. Benko. While the other students commonly complained about the ESL teacher or curriculum, Yelena's only unhappiness came from her Soviet Evangelical peers. She resented their disruptive behavior and the time it took away from a lesson by forcing the teacher to interrupt class and discipline them. The angry tone of Yelena's voice underscored her resentfulness.

In discussing their feelings toward education and ESL, Peter and Dimitri brought up the value of an education. Many Soviet Evangelicals do not place a high value on education as a result of years of denial to higher education institutes and harassment at school due to their religious beliefs. This issue has been considered, by some educators working with Soviet Evangelical students to be one factor strongly and negatively affecting their ability to successfully adjust to the U.S. school system.

Peter stated that he had never liked school. When he left the former Soviet Union he was attending night school in order to complete his General Education. This was preferable for him because he only had to go one night per week. His mother, he said, felt school was important, but "didn't bother us [him and his siblings] about school." His father on the other hand, did:

My father watched us. He told me to work harder if I get bad grade. He told me I am good son if I get good grade. I was so-so student.

Dimitri said that school was important, but that he was just not interested. His 
disinterest and lack of motivation stemmed from his early knowledge that as a Christian in the former Soviet Union he was automatically excluded from higher education, or university:

I could go, just not go to big university. You need to be Communist. It was problem to go to big college for Christians.

Even though he is now attending a U.S. high school and college is open to him, Dimitri says he still feels bored and disinterested in school:

Here [in the U.S.] school is kind of bored, so I want to stay home. My mother gets mad because she thinks school in America are more important than Russian schools. Because you study English.

Peter and Alex, the two students most dissatisfied with ESL, believed they were not learning much in the class. This they blamed on the ESL teacher. As Alex explained:

I feel bad in ESL class now. The first time [at his previous school] was better because I studied a lot more words. Now nobody explains things to me. ESL is not interesting. When the class is repeating a lesson, I feel like I'm wasting my time. I do my homework and classwork, but I'm not happy. I want to study in a different program, more effective. In the Soviet Union I can do three books instead of one. I'm mad at the teacher. I call her four, five, six times to come help me and she doesn't come.

Peter, who claimed to have liked ESL one year ago, now felt it was boring. He intended to withdraw from it soon because "everybody in the class is like little kids." "The teacher," he complained, "talks to the students like they are little kids." He continued, "They [the teacher] think because we are from other countries we don't understand things."

When Alex, Peter, and Dimitri were asked how they would change the ESL program more to their satisfaction, Alex and Peter expressed the desire for a more Soviet style 
curriculum and teaching approach. Peter wanted more direct instruction about English. stressing grammar and pronunciation. Alex also wanted a stronger focus on English grammar and more assignments. Dimitri's strongest wish was an ESL teacher that would ask the students what they wanted to learn.

All three felt they could not approach Mrs. Benko with their complaints and suggestions. "Because she is old, she knows better. I don't tell her how to change ESL," was Peter's explanation. They also feared offending or angering Mrs. Benko and implying that she was not capable of doing her job. The only solution in their view was to simply tolerate ESL until they were proficient enough to exit the program. This reluctance to speak with Mrs. Benko is typical for Soviet students, who are taught from the beginning of their school years that the teacher is the ultimate authority in the classroom and possesses all the necessary knowledge with which to teach the class. Openly disagreeing with teachers or questioning their abilities, methodologies, or any other aspect of their teaching was prohibited. To do so would be offensive and disrespectful behavior towards the teacher.

\section{CLASSROOM BEHAVIORS}

Five behaviors frequently exhibited by Soviet Evangelical students were identified by the ESL instructor and her classroom aide. They described these behaviors as being "out-of-control" and "terrible". This included blatant discrimination toward other students, cheating, high absenteeism, a resistance to authority, and incessant talking. While these behaviors are certainly not limited exclusively to Soviet Evangelical students, the magnitude of these behaviors and their impact on the ESL classroom 
makes them noteworthy. They also quickly earned the Soviet Evangelical students a negative reputation among the ESL and DHS personnel as "difficult" and "disrespectful" students. The ESL classroom assistant summed up the feelings of other DHS staff when she said, "They [the Soviet Evangelicais] can be nice kids, but I just want to know why they do what they do."

\section{Discrimination}

A continual problem bubbling below the surface of the classroom environment and occasionally rising to the top was tension between the Soviet Evangelical students and those from other countries. This tension was often tangible. During class breaks, the Soviet Evangelical students usually congregated in one area of the classroom, while the other ESL students (primarily Asian) kept to themselves in another section. The two groups rarely, if ever, mixed. This situation was of great concern to both the ESL teacher and staff assistant. They were constantly watching for potential problems.

All nine of the study's participants claimed not to harbor discriminatory feelings towards their classmates. This went against their religious teachings. Alex, involved in a disturbance during the semester with a Vietnamese student, spoke at length about his feelings on discrimination. "They are people like me," he said. "No reason for it [discrimination]." When asked about his altercation with his classmate, he said it was the wrong way to behave:

Instead, one must be quiet. There is no reason to fight and argue. I like everybody...God made everybody. God doesn't look at color. He looks at heart.

However, the students' words did not always match their actions. Evidence of 
discriminatory behaviors by Soviet Evangelicals included making fun of the Vietnamese students' nasal-sounding English as they spoke. They also refused to work with them. explaining they could not understand their English and therefore needed to work with their friends.

\section{Cheating}

This behavior was simple for the Soviet Evangelical participants to explain. In short, cheating, as defined in American culture, is viewed in Soviet culture to be "helping" or "sharing one's information or knowledge." This definition has its roots in Soviet culture, where egalitarianism and interdependence are favored over individualism and competetition. All the participants were cognizant of the different perspectives and definitions between the two cultures regarding cheating, and were also aware that in the U.S. classroom, cheating was an unacceptable behavior.

The students acknowledged matter-of-factly that cheating is practiced by Soviet Evangelical students who attend U.S. schools. When asked why this is done, especially when the students understand that it is unacceptable and punishable, most students cited the cultural differences. They stated that in their culture, if one student knows the correct answer, he/she is expected to share it with the rest of the class. Everyone wants and needs good grades, they explained, so students help one another by sharing answers. This then, was not cheating, but rather helping or sharing.

In addition to the cultural differences explanation, the students offered other rationales. These included Nick's theory that Soviet Evangelical students cheat because "maybe they just don't study. They just don't want to get a bad grade." "I just don't 
want to think," was Dimitri's explanation. "You don't want to get your brain used up." Laziness was Alex's excuse. He explained, "Sometimes you're lazy. You don't study. But I need good grades." Cheating then, is used as a means to achieve a good grade or to compensate for a student's lack of preparation.

When asked if cheating contradicted their religious teachings, the participants said no. All claimed to not feel guilty about cheating. Dimitri emphatically stated, "No, I never feel bad! Why should I stop?" Alex said he didn't know how to explain why cheating didn't bother his conscience. For him, it was something that he had always done, just like everyone else in his Soviet class. He defiantly added, "I don't care if the teacher gets mad." One Russian national interviewed for this study explained that the lack of guilt over cheating was a result of the Soviet cultural habit of "trying to beat the system." Bureacracy, paperwork, school examinations, or anything or anyone that wielded authoritative power was open to challenge. It was a great source of satisfaction to an individual to win and "beat the system." The informant added that it was common for teachers to turn a blind eye to cheating.

Finally, strong pressure from peers and the consequences one suffers if unwilling to share his/her knowledge with the rest of the class seem to prevent Soviet Evangelical students from abandoning this cultural practice. The phrase "mother's son" was used by Alex to describe a classmate who refused to share answers. He added, "If you don't help the others, they will say you are 'different.' A student may also be ostracized from his/her peer group. Dimitri laughingly added, "The kid who doesn't tell the answers gets a bloody nose." 
Some students, such as Alex and Peter, were quick to point out that cheating is not just a Soviet Evangelical phenomenon; that their American classmates also practice it. Their observation is backed up by a recent survey conducted by Who's Who Among American High School Students. The results of their 24th Annual Survey of High Achievers showed that of the 1,975 B average or higher secondary school students surveyed, $40.3 \%$ confessed to having cheated on a test or quiz. Eighty percent believed widespread cheating to be common and admitted to having cheated one way or another. Types of cheating included copying someone else's homework, plagiarizing parts of an essay, or using Cliff Notes to avoid reading a book (Graves, 1993).

Observing the class during an exam, the researcher saw, among the Soviet Evangelical students, roving eyes and craning necks, but no overt "sharing answers" by talking or other means. The students appeared to be accustomed to the ESL teacher's watchful eyes during a test. Maria, noticing Mrs. Benko scan the room for students using hidden notes, caught the teacher's eye, smiled broadly, pointed, and said, "Mrs. Benko, my books are over there."

\section{$\underline{\text { Absenteeism }}$}

The attendance figures for the semester in which this study was conducted demonstrate a high rate of absences among Soviet Evangelical students. This high rate, according to DHS school personnel interviewed, is not unusual and has been a chronic problem since Soviet Evangelicals began enrolling at the school.

During the first semester ( 90 days) of the school year, there were a total of 137 absences among 13 Soviet Evangelical students, an average of 10.5 absences per 
student. The least number of absences was three, the highest was 25 . This student, however, later withdrew from school. Among the other ESL students there were 34 absences, with an average of 4.8 absences per student. This is less than half that of Soviet Evangelical students. The greatest number of absences for other students was 27, and this was considered by the ESL teacher to be a special case due to that student's personal problems. The next highest number of absences was 14. The least amount was 0 . It was an additional concern to the ESL staff that $70 \%$ of the Soviet Evangelical students' absences were "unexcused", meaning that the absence was for a reason other than the reasons deemed acceptable according to the school's attendance regulations.

Initially it was thought by the ESL staff that Soviet Evangelical students were often absent because of church related activities or family reasons, such as accompanying a parent to an appointment to act as an interpreter. Students recently arrived in the U.S. were frequently in need of extensive dental work and thus missed classes due to several dentist appointments. The Soviet Evangelical students, however, disagreed with these assumptions. According to them, their main reasons for staying home from school were boredom with their classes or simply feeling too tired to get up. Peter, for example, said many of his absences were legitimate, such as a dentist appointment or family matter, but confessed that he often stayed home because he was tired. His high absenteesim and missing school did not bother him, he claimed.

The school where this study took place previously maintained a strict attendance policy that has since been changed. Even this previous strict policy and its repercussions did not deter the Soviet Evangelical students' propensity for absenteeism. 
Some Soviet Evangelical students who understood the attendance policy and admit procedure, defined in Chapter II, would write their own excuse, citing a legitimate reason for their absence, and then have their parents sign it. The school's attendance office often called parents to report a student's absence. Many Soviet Evangelical parents, with limited English skills, did not understand the call. The students would either tell their parents not to worry or fabricate a reason to explain the call. Julia, who worked one period as a student aide in the attendance office confirmed that these were indeed true. "I see excuses and I know they are not true. Many people just stay home and write different excuse."

It was noted by several students that American students can also frequently be absent from school. Many of these absences are due to unexcused reasons such as truancy. Dimitri commented that some American students had told him that when they "skip" or are truant, they are punished by the school. When Soviet Evangelical students skip, they do not suffer any punishment or are treated differently by school officials. Dimitri was not sure if this accusation was true or not, but did feel it was unfair for the American students to label the Soviet Evangelicals as "skippers" when they engaged in the same kind of behavior.

\section{Resistance to authority}

DHS staff members interviewed for this study recounted that upon their initial involvement with Soviet Evangelical students. they sensed a strong resistance towards them and their authority by the students. The staff members were confused by the outward combativeness of the students that took the form of anger, defiance, and terse 
speech. All remembered wondering why the Soviet Evangelical students seemed to be constantly belligerent.

The ESL classroom aide spoke of repeated requests for students' attention being ignored or met with an angry retort. Some students turned their backs to her while she was teaching.

According to Richmond (1990), "Russians have a deep and abiding suspicion of government" (p.67). This suspicion has evolved from centuries of authoritarian rule in Russia. As a result, an anarchic strain has developed in Russian behavior, with "rebellion against regimentation and a flouting of regulation when they believe they can safely do so (p.86). This is referred to by Zevereff (1992) as a "siege mentality and combativeness" (p.1). One Russian national interviewed for this study described this combativeness as a public behavior one uses to interact with authority figures. An example of this "rebellion against regimentation" and a common "flouting of regulations" involved parental signatures for school papers, such as field trip permission slips. It was common practice for the Soviet Evangelical students to forge their parents' signatures on these papers. The ESL teacher remembered passing out papers requiring a parental signature and minutes later receiving signed papers from the Soviet Evangelical students. When she explained to them that they needed to take the papers home and have their parents sign them, the students balked. They complained that their parents did not like to be bothered with such things and why should they take the papers home anyway when they could sign them themselves and save the trouble of having to take the paper home and bring it back. The ESL teacher found this behavior amusing, but 
also a little disconcerting that the Soviet Evangelical students held so little regard for rules and regulations.

\section{Talking}

The continual high noise level of the ESL classroom was primarily due to a constant undercurrent of conversation, usually amongst Soviet Evangelical students. Mrs. Benko frequently had to stop her lesson to ask a pair of Soviet Evangelical students to stop talking. The classroom assistant felt that she was always competing with the students for their attention.

Eight of the nine participants readily acknowledged that they all talked during class at inappropriate times. Why they did it was difficult for most of them to explain. Most laughingly said that talking just seemed to come naturally for them. Nick, one of the more well-behaved and cooperative students, but also prone to talking, smiled as he admitted, "I kind of talk too much. Sometimes it's hard not to talk." In a more serious tone he added that the other students were not very smart to talk so much because they were always being reprimanded by the teacher. Nick felt he was able to control the temptation to chat with his Soviet Evangelical classmates because "sometimes I just want to do my own work and not worry about getting in trouble."

Maria, Olga, and Julia began to laugh when asked about talking during class. Maria explained in an almost self-deprecating manner:

Talking is hobby, so I just do it. Is that way for all Russians and Ukraines. It's not OK, but I just like to do it. Sometimes work is boring so I just talk.

However, Yelena held a different view of talking. This behavior angered her because of 
the interruptions and distractions it caused during a lesson. She was also embarrassed that the offenders were often other Soviet Evangelical students. She was concerned that they were making Soviet Evangelical students "look bad" to other classmates and teachers.

The fact that ESL was often the only class that Soviet Evangelical students were all together was put forth as another rationalization for talking. As Alex pointed out, in his non-ESL classes he was with American students and felt he could not really talk with them. In ESL though, his friends were there, so the desire to talk was great. He also noted that in his Russian school students could joke with the teacher and visit quietly with friends after completing their assignments.

While attending a Soviet Evangelical church service, the researcher noticed that throughout the more than two- hour worship, many members were quietly visiting with one another. Mothers were quietly entertaining their small children and young people were visiting with one another. No one was told to stop talking and be quiet. It was simply a part of the service that ceased only when it was time to pray. Once a prayer finished, the talking resumed.

\section{Other behaviors identified by ESL teachers}

Two other smaller behaviors, disorganization and leaving the room without permission, were identified by both the ESL teacher and classroom aide as typical of their Soviet Evangelical students. Both behaviors are easily accounted for through cultural explanations. 
Disorganization. As explained in Chapter II, students in Soviet schools carried one notebook that contained all their work. The teacher and often their parents closely monitored this notebook and it was given to the teacher on a regular, almost daily basis. This "homework log" system is not used in U.S. secondary schools. Instead, it is the student's responsibility to keep account of papers, assignments, and many often have several notebooks to maintain.

The nine interviewees all found this system difficult to adjust to. Most stated it was a challenge for them to keep their papers and notebooks organized. They felt they often had too many papers, textbooks, and notebooks to keep track of. All agreed that the Soviet system of one notebook for everything was much simpler.

Leaving the room without permission. Both the ESL teacher and classroom aide expressed indignation that their Soviet Evangelical students would simply get up and exit the classroom during a class period. Both had repeatedly explained the school's use of hall passes students were required to obtain from the teacher when leaving during a class. Some students remembered to ask for one, but others persisted in walking out of the room at any time. Hoot (1993) explains that in Soviet culture one does not discuss his/her bathroom needs. Something as simple as blowing one's nose is not done in front of others, and is considered impolite to do so. Students are required to give a reason why they are requesting a hall pass and, therefore, might be hesitant to tell the teacher they need to go to the bathroom, as it violates a cultural norm. Older students may simple walk out of a classroom without permission, as a way of resisting the teacher's authority (New Soviet refugee, 1990). 
This chapter has examined the cultural and educational values and experiences that form Soviet Evangelical students' orientation to learning and classroom behaviors. These two areas were addressed in order to account for and demystify the often confusing, frustrating, and culturally inharmonious behaviors Soviet Evangelical students routinely exhibit in the classroom.

It was noted that Soviet Evangelical students bring with them their own cultural and educational beliefs and experiences that strongly shape their attitudes towards learning and classroom etiquette. It was also noted that the students have entered a new educational system that differs considerably from the one in their native country. It also features a different approach to learning, different teaching methodologies, and expectations of student behaviors.

The values and beliefs of Soviet Evangelical students are often strongly maintained, resulting in a culture clash with their American teachers and other students. Even when the students have acquired an understanding of appropriate U.S. classroom behaviors, old behaviors may still persist. This underscores the need for ESL teachers and other school personnel working with Soviet Evangelical students to have an understanding and knowledge of Soviet cultural and educational values so as to be fully prepared to confront these behaviors and avoid the mistake of assuming that Soviet Evangelical students are simply or purposefully being difficult or uncooperative. 


\section{CHAPTER VI}

\section{THE ACCULTURATION PROCESS}

The study's final guiding question, "After residing for one year or more in the U.S., How do these factors affect their adjustment and acculturation to American schools and culture after having resided in the U.S. for one year or more?", is addressed in Chapter VI. The students discuss their plans for the immediate future and the kind of life they envision leading in 1999 , five years from the time the study was conducted. The students also reflect on the personal changes they have undergone since emigrating to the U.S. and how these will affect their future lives. Finally, school personnel discuss their opinions regarding the future of Soviet Evangelicals.

\section{FUTURE CHALLENGES FACING SOVIET EVANGELICALS}

Two challenges all immigrants face in acculturation are creating an independent and self-sufficient life for themselves within their new environment and maneuvering between their native identity and culture and their new, adopted one. These challenges are no different for Soviet Evangelicals and in some ways more difficult given the extreme differences between Soviet and American culture, society, and language. The fact that the Soviet Evangelicals' purpose in coming to America was to maintain and freely practice their religious beliefs only heightens this challenge.

For adolescent immigrants, such as the nine participants in this study, there are these 
two challenges and additional ones. These include adjusting to a new school system with a different set of rules and regulations, teaching methodologies, daily routines, and expectations of student behavior. Trying to adjust to the norms of the new culture while maintaining those of their native ones is also difficult, especially when approaching young adulthood and trying to establish one's own independent identity. Helping parents with weak language skills in the new language is a new and sometimes unwelcome responsibility adolescent immigrants face.

\section{FUTURE PLANS}

In the former Soviet Union, the future plans of a young Soviet Pentecostal would have been quite simple. Young men would begin working at about age 17 or 18 , typically at a blue-collar trade. Marriage would come later, usually in their early to mid-twenties. For young women, marriage would also take place early, sometime during their late teens or early twenties. They usually entered traditionally femaledominated occupations of childcare, nursing, bookeeping, cooking, housecleaning and sewing (Specific Questions, 1993). After the arrival of children, their careers as housewives and mothers would start. Since the opportunity for higher education was closed to Soviet Evangelicals, thus eliminating any chance of obtaining a white-collar job, this scenario of the Soviet Evangelical future was true for the majority of members and rarely changed. A few did succeed in receiving some advanced form of education, usually with the aid of a sympathetic teacher. This, however, was uncommon.

The immediate future plans of the nine participants blended the traditional Soviet Pentecostal marriage and children at a young age with the typical post-high school plans 
of higher education and a career. This was true of both males and females. The freedom to study at a university was a clear influence in their future plans, as all but one participant indicated a desire to pursue some type of higher education. Only one student saw himself returning to live in his former homeland. The rest wanted to visit, but would not stay permanently because of the unstable political and economic situations in the former Soviet Union. Most expressed a satisfaction with their lives in the U.S. and considered their emigration a permanent one. The future plans of the nine participants are as follows:

Alex. Studying auto mechanics at the school district's vocational program at the time of this study, Alex wanted to go to college after graduation. When asked about marriage, he replied, "Of course!"

Julia. Each of Julia's plans for the future was prefaced with the word "maybe". "Maybe a little college," she speculated. "Maybe get married around age twenty." "Maybe I will wait a little bit." She was not sure what field of study she would go into.

Nick. In 1999, Nick would, "go working like regular people." He was not sure what kind of work, but something involving computers, since, "I like computers." He wanted to attend college, but marriage was only an unenthusiastic, "Maybe, I don't know."

Maria and Olga. The two sisters first stated that they would be "waiting for God, Jesus to come." While both wanted to go to college, only Maria had selected a career. "Something about airplanes," she enthusiastically described. "How to fly and be a stewardess." Both were definitely not returning to Ukraine. Some people were returning, they explained, "Because God told some people to go back. They don't like it 
[America]." Maria and Olga insisted that they were not part of that group.

Peter. By 1999, Peter saw himself, "living in America", "working", and "of course, married." The marriage response was accompanied by laughter, indicating he was not serious about this plan. Peter had thought one year ago about returning to Russia, but now said he would not go back because of the political situation. He would only "go back like a visitor."

Ven. Ven struggled to answer this question and finally said he thought he would attend college. Other questions about what he would study, marriage, and where he would live, were answered with a soft, "I don't know."

Dimitri. Dimitri predicted, "I will probably go back to Russia to live." If this was not possible, he saw himself remaining in the U.S. He sometimes thought about attending college, "but if not, I can get job with cars with cousin in his body shop."

Yelena. Yelena wanted to attend the local community college after graduation, but was not sure if it would be possible. "I don't know how I can study," she worried out loud. "My parents go also to college." Because her parents were currently attending the same local college, Yelena was not certain there would be enough money for her to begin classes in the fall. She hoped to study computers so that she could "work in an office."

\section{MAKING THE TRANSITION}

The nine participants were asked to assess the personal changes they had undergone since living in the U.S. for at least one year. All acknowledged that being in the U.S. had had some effect. Most cited forgetting Russian words and grammar and of feeling 
more confident in confronting the newness of American culture and daily life.

Peter said that his mother had remarked to him on several occasions that he was behaving less "Russian-ly" and more "American-ly". "This made me feel good," he said. "There is nothing wrong with it."

Dimitri stated that his parents had also told him he was acting more American, something which he vehemently denied. He himself did not feel he was changing as the result of living in the U.S. Instead, he claimed that he was forced to acquire new American behaviors, such as having to call home if staying out late with his cousins, something he said he never had to do back in his homeland. He continued that his parents were the ones who were changing, since they now had incorporated such typical American parental behaviors as grounding him for misbehavior. Dimitri did not want to adapt to American culture because as he saw it:

American kids look stupid. They look like bums. They're not as fun as we [Soviet Evangelicals] are. I can't explain but seems like, "Don't do this." They don't know how to relax and have fun.

Nick, one of the longest residents in the U.S. among the study's nine participants recalled that earlier in the school year his fifth period American classmates were surprised one day to discover that he was Russian. Several commented that he did not look or sound Russian. Nick was not sure what to make of this, except that it must mean he was becoming more American. He said he did not feel like he was changing. He saw American teenagers as being the same as Russian ones, although "Americans sometimes think they're better than Russians." "They're loud and smiling but they don't really mean it." This was a trait he hoped he would not acquire. 
Nick and Dimitri were not alone in their wish to avoid becoming Americanized.

Although Ven held the philosophy that, "If you live in one country you do like people in that country", he felt that he was not changing. Like the other two, he was critical of some common American traits:

Americans smile too much. Russians show what they feel. If they're happy, they smile. If not, they don't. How [one] can learn person's character.

The same question about personal changes elicited a similar response from Olga, Maria, and Julia. None felt that they were becoming Americanized. Instead, Olga and Maria spoke of their pride in being Ukrainian and all three began to vent their frustrations about American characteristics they disliked, such as being critical of others. Julia spoke of overhearing her American peers talk about "how Russians were all on welfare" and questioning how a Russian family could get a nice car so soon after emigrating to the U.S. She said:

Russians know how to work. We can take an old car and make it good. Americans are lazy. They think we just take welfare, but we work. They're jealous because we come here and soon we have good things. We work for them.

Olga and Maria added that they had heard similar criticisms. They added that they sometimes felt an unfriendliness from their American classmates. This unfriendliness consisted of staring, ignoring them, and mocking their dress, mannerisms, and speech. Maria remembered with anger how one day at school, a group of boys came up to her and began pulling her long pony tail and making fun of her second-hand clothes. These incidents had left them with a definite distaste for Americans and American culture.

The most interesting response came from Alex, because it revealed feelings of 
isolation and unhappiness in his new culture. He could not say whether he had taken on any American traits because "I don't know very much about Americans." He admitted to not having many American friends. "I don't understand Americans and they don't understand me," he explained. "They're not mean, only they just don't care." When asked if this bothered him, as it appeared to by the somberness of his voice, he replied:

It doesn't matter where I live. I just want to be by myself. I just want to be Alex. I know what I need to survive. Just be a good person. I'm a Believer. People who believe in God survive.

While the question, "How have you changed after one year in the U.S.?" did not elicit the anticipated responses of students reflecting on their personal changes, it did result in a discussion of American versus Russian personalities, and frustrations with American behaviors. There appears to be a clear "us" and "them" distinction and a strong identity as a Soviet Evangelical, for all the participants. The participants may live and function within American culture and society, but first and foremost they are Soviet Evangelicals and apparently wish to remain identified as such and separate from Americans.

\section{THE FUTURE OF SOVIET EVANGELICAL HIGH SCHOOL STUDENTS}

Roberts (1991) predicts that for the Soviet Evangelical community "acculturation will be slow because of extreme cultural and social differences" (p.33). Another hindrance lies in the fact that the Soviet Evangelicals' purpose in coming to America was to freely practice their religion and maintain their lifestyle. After years of government persecution that forced them to live and practice their faith clandestinely, there is a strong desire among members to live their lives and faith openly. Finally, 
what is perhaps one of the greatest strengths in Soviet Evangelical culture, the closeness of their community, is also a roadblock to acculturation. Their strong in-group identity and avoidance of non-believers lead to limited contact with Americans and the English language.

According to the DHS ESL teacher and other school personnel interviewed, they have found the above to be true and name other factors affecting the future success and acculturation of Soviet Evangelical students. They also feel these are reasons why the majority of Soviet Evangelicals have difficulties adjusting to the U.S. school system and are also the slowest cultural group to exit the ESL program.

The school counselor, who advises Soviet Evangelical students on post-high school plans and career goals, named several problem areas. These problem areas often result in the student leaving school early, without a diploma, which negatively affects Soviet Evangelical students' chances to create for themselves not only a successful and self-sufficient future, but also the opportunity to learn the skills necessary for achieving this.

One problem area the school counselor noted was the failure to realize the importance of earning a high school diploma. The counselor attributes this to the Soviet Evangelical students' lack of cultural knowledge regarding the U.S. education system and workplace. The majority do not comprehend, in her opinion, that a high school diploma is a necessity when attempting to find work, especially a position that pays more than minimum wage and carries some kind of future with it.

Related to this is the tendency of Soviet Evangelical students, especially males, to 
drop-out of school after acquiring a level of English sufficient for securing a job. Most students found minimum wage work in the blue-collar or service industry sectors. In the students' eyes, the minimum wage they were earning was a lot of money, and therefore, they saw no reason to continue with school. School simply interfered with their money-making opportunities.

The school counselor partially blamed this on the Soviet Evangelical cultural practice of young men entering the work force at age 18. She acknowledged that this was a strong cultural difference to overcome and trying to convince the students that they would probably find better jobs with high pay if they simply stayed in school for another year or two was difficult.

The ESL classroom aide strongly felt that the behavior of Soviet Evangelical students was and would continue to be their greatest roadblock to a successful transition to the U.S. classroom. In her opinion, Soviet Evangelical students "just want to do everything their way and disregard the rules." Students were not adapting or changing their behaviors to those practiced and valued in the U.S. classroom. This stubborn clinging to Soviet behavior was due to, in her view, the students misinterpreting the meaning of freedom. Soviet Evangelical students, she said, consider freedom a fundamental component of American culture. However, they misconstrue this to mean they may do whatever they want, whenever. It will be necessary for them to learn to behave within limits and to develop a respect for rules and regulations.

A second roadblock was what the classroom aide termed "priorities." Similar to the school counselor's observations, she saw a low priority on education and a higher one 
with families and survival. Students were willing to sacrifice school and their education in order to meet family obligations. The classroom aide felt that the Soviet Evangelicals needed to fully understand that the children belonged in school, not at home.

The ESL teacher focused her answer primarily on the strong in-group identity among Soviet Evangelical students. Since other cultural groups in the ESL class were smaller and tended to interact more with one another, English was practiced more often, as it was needed for communication. This gave the students more opportunities to use and practice their English skills. This was not the case with Soviet Evangelicals, who stayed close together, speaking in Russian. This, of course, decreased their use of English, and was seen as a factor in their lengthy time spent in the ESL program. The ESL teacher believed that this strong group identity affected not only their language skills, but their overall ability to adjust to the U.S. classroom and American culture in general.

While the majority of the nine participants expressed negative views regarding Americans and American culture, and demonstrated a strong resistance to adapting behaviors and values necessary for a successful transition to the American classroom, the ESL teacher, classroom aide, and school counselor all expressed optimism concerning the future. They acknowledged that Soviet Evangelical students were experiencing a slow and difficult transition period, but that they had made progress in confronting the problems that hinder the students' acculturation. They pointed out that some of the early arriving Soviet Evangelical students have graduated and that others, such as Yelena, are demonstrating an understanding of the behaviors and values 
necessary for success not only in the U.S. classroom, but also in American culture.

They believed that the number of Soviet Evangelical students who were able to succeed in the classroom and earn a diploma would increase, as the younger siblings of the current group of students entered high school with a greater amount of experience in and understanding of the American classroom. 


\section{CHAPTER VII}

\section{CONCLUSION AND RECOMMENDATIONS}

This study has documented the educational and cultural experiences of Soviet Evangelical high school students, the most recent refugee population to the PortlandVancouver school districts. Virtually unknown as a cultural group upon their unexpected arrival in 1988, their rapid influx resulted in a demographic shift in many Portland-Vancouver ESL classrooms. The students have been labeled as "difficult" by ESL instructors and other school personnel working with them because of their often disruptive classroom behaviors. The majority of the Soviet Evangelical students have done poorly in American schools and have had a noticeably difficult time adjusting to the U.S. classroom (Specific Questions, 1993; Zvereff, V., 1992).

The main goals of the study were to detail the experiences of Soviet Evangelical high school students who have transitioned from the totalitarian and collectivist-oriented Soviet culture and classroom to the more open, individualistic American one, using the students' own words, and to create a cultural and educational frame of reference for ESL educators and other school personnel. This was completed through ethnographic interviews in which the participants described their experiences of attending a U.S. high school for at least one year. Interview questions focused on such topics as the differences the students perceived between the Soviet and American classrooms, their 
attitude towards education, and how they see themselves after one year in the U.S. The participants also accounted for the behaviors cited by ESL educators as being most frustrating. Interviews with the participants' ESL teacher, classroom aide, and others outside the Soviet Evangelical community with knowledge of Soviet culture were conducted, along with class observations, and a language learning preference survey.

The results showed that the Soviet Evangelical students came to the U.S. with high expectations of a good life in America, but with little, if any knowledge of American culture and the education system. Feelings of loneliness, homesickness, and frustration quickly set in upon encountering the new language, new school routines, and rules and regulations, some of which make no sense to the students. This is consistent with the initial stages of acculturation and culture shock, where an idealization of the new culture is followed by disappointment once the newcomer realizes life is not as he/she expected (Belozersky 1992). Culture shock can be particularly acute for Soviet Evangelicals, as many believe America to be the promised land where they will be able to live and practice their faith freely. Gradually, the newcomer recovers from this shock and begins to adjust to the new culture. This eventual recovery was slow to take place among the Soviet Evangelical students. Only one student, Yelena, was identified by the ESL teacher as having adapted to the U.S. classroom. Others, such as Nick and Julia, felt comfortable, while others, including Peter, Dimitri, Ven and Igor, were still struggling to adapt, even after a year or more at their American high school.

The educational and cultural values that form the Soviet Evangelical students' orientation toward learning and classroom behaviors was found to play a strong role in 
the transition process. It also helped to demystify and account for the behaviors ESL educators found so difficult to deal with. The results of the language learning preference survey showed the participants to be both communicative and authorityoriented learners. While they revealed a preference towards some American style approaches, they also demonstrated a high liking for more Soviet style ones. In discussing the classroom and teacher, responses again indicated a strong tendency towards those attitudes and values representative of the Soviet school system. These included the beliefs that the teacher was the ultimate authority in the classroom, and that openly disagreeing with a teacher was unacceptable. Classroom behaviors also reflected their Soviet attitudes and values. Students continued to behave as they would in a Soviet context, even when the appropriate American classroom behavior was understood. These Soviet behaviors, such as "sharing answers" on an exam, often clashed with American behaviors expected in the U.S. classroom. The result was a culture clash between the ESL teacher and the Soviet Evangelical students and a high frustration level among both groups.

In addition to adhering to Soviet style behaviors and values, the students demonstrated a strong in-group identity. The participants expressed satisfaction living in America and saw themselves as permanent residents, but also professed a distaste for many of the behaviors and personality traits of their American peers. Typical of Soviet Evangelical culture, where contact with non-Believers is often avoided, the students preferred to interact within their own community. This is evident by their classroom actions. Soviet Evangelicals rarely interacted with their non-Soviet ESL classmates, 
and consistently refused to work with them in small-group activities. The participants had few American friends, and one participant confessed to not knowing much about Americans or American culture, even after residing in the U.S. for over one year. Strong feelings of nationalism combined with the Soviet Evangelical religious practice of avoiding all "outsiders" or "non-Believers" may be seen as accounting for this strong in-group identity and infrequent contact with both Americans and their non-Soviet ESL classmates.

In summary, the findings of this study are consistent with those of Roberts (1991) and Wiggins (1994), the two most recent studies of Soviet Evangelicals. Roberts' prediction of a slow and difficult period of acculturation for Soviet Evangelicals was found to indeed be the case, as the Soviet Evangelical students attending the high school used for this study were the slowest cultural group to exit the ESL program, often taking up to three years to complete it, and some were still struggling to adjust to the American classroom after one or more years of attendance.

Wiggins' assertion that ESL educators need to consider the differing educational and core values of Soviet Evangelical students when choosing teaching methodologies was also found to be a factor in this study. The Soviet Evangelical students surveyed for this study indicated a preference for familiar, Soviet-style methodologies, such as having the teacher explain everything and telling students all their mistakes. The desire of two participants for the ESL teacher to use a more direct teaching approach stressing grammar and pronunciation is another example.

Religion, originally thought to strongly affect Soviet Evangelical classroom 
behavior, was claimed by the participants to not be a major issue. When asked if their religious convictions played a role in their classroom behaviors, the nine participants categorically denied it. In their view, school was school and church was church. As Peter explained, "If I don't want to celebrate holiday, I stay home." This was in reference to holidays such as Halloween, which Soviet Evangelicals disapprove of with its emphasis on what they perceive as occult themes.

Similar to the denial of discriminatory behavior toward non-Soviet Evangelical classmates, the participants' words did not match their actions. An example of this took place at the beginning of the school year. An illustration of Death that accompanied a folktale in the reading textbook used in the intermediate reading group generated complaints from several Soviet Evangelical student who termed it "satanic". They refused to read the story or use the textbook. The ESL teacher firmly explained to the entire class that the drawing was not satanic, but part of a story. She then stated that this was the textbook used for the class and that she expected everyone to use it. The lesson resumed. After that, there were no more complaints, at least overt ones, from the Soviet Evangelical students. This is not to say however, that perhaps they were "disagreeing inside" as Soviet students were forced to do in their former schools.

In spite of the slow and difficult acculturation period that the high school used in this study was experiencing with its Soviet Evangelical students, acculturation did seem to be taking place. The participants in this study, with the exception of one, all expressed a desire to attend some form of post-high school education. The students were making career plans and planning a future for themselves as permanent residents. One 
participant, Yelena, was set to graduate in the spring and it appeared several others would successfully complete their studies. As younger Soviet Evangelical students enter high school with a longer period of attending an American school and studying English, this long, and slow acculturation process may be completed. The students will also be better prepared to meet the challenges of high school, having had a chance to learn specific classroom skills, expected behaviors, American teaching methodologies and approaches, daily routines, and the many school rules and regulations, all of which caused difficulties and frustrations for their less experienced older siblings. The ESL teacher speculates that the new arrivals are being helped by the longer residents, who are informing them about American schools. She thinks that this "peer coaching" will help new students adjust more quickly to their new school. The ESL teacher believed that after five years of working with Soviet Evangelical students, her job was becoming slightly easier, as both teacher and students adjusted to one another, and both acquired the necessary skills to work together and reduce culture clash.

\section{RECOMMENDATIONS}

\section{Future Research}

Three recommendations are made for future research on Soviet Evangelical high school students. The first is to conduct a follow-up study. As the participants predicted what their lives would be like five years from the time the study took place, it would be interesting and useful to track them, in order to see if these predictions manifested themselves. Another area of interest would be to follow their acculturation process as it continues, in order to see if the students were able to successfully develop their own 
identity and self-sufficiency in their new homeland.

A second recommendation is to expand the focus of research. This study concentrated on the cultural and educational values of the nine participants. This could be expanded, through the use of surveys and interviews, to other values, including job and family. This additional information would increase the frame of reference ESL educators and others would have to draw from.

Finally, a study focusing on gender differences would also be of interest. Specific areas to compare between male and female Soviet Evangelical students include learning styles and behaviors.

\section{Recommendations for ESL educators and others working with Soviet Evangelical high school students.}

The following recommendations have been complied from journal articles and informational handouts authored by ESL teachers, Soviet nationals, and others familiar with Soviet culture (Hoot, 1993; Irwin, 1991; Roberts, 1991, Specific Questions, 1993; Zvereff, V., 1992). The ESL teacher and classroom aide interviewed for this study also contributed ideas. These ideas are presented in the form of issues and recommendations.

Issue 1: Soviet Evangelical girls are hesitant to speak in class in the presence of boys. Recommendations:

- Create a comfortable classroom setting that will encourage girls to speak.

- Re-arrange the classroom seating.

- Include some separate-sex classroom activities. 
Issue 2: Inappropriate classroom behaviors including talking, showing disrespect for the teacher's authority, and discrimination toward non-Soviet peers.

\section{Recommendations:}

- Use firm, fair and consistent discipline. Soviet Evangelical students are accustomed to strict school discipline. American-style punishment will not be as severe as they are used to, and therefore not taken seriously. Tying discipline into the church and their parents can sometimes help, as they are power structures many Soviet Evangelical students respect.

Issue 3: Difficulty adjusting to the American classroom.

\section{Recommendations:}

- Create a familiar and comfortable atmosphere, especially during the students' initial period in the classroom. For example, allow students to decorate at least part of the classroom, as they did in the former Soviet Union.

- Include some Soviet-style types of instruction and learning activities, such as rote learning and teacher-fronted activities. Slowly introduce them to American-style learning activities.

- Provide new students with information about the cultural and educational differences they will find within the American classroom along with the new rules and regulations, behaviors, and routines they will need to follow. If possible, do this in their native language.

- Use a buddy system. Pair new Soviet Evangelical students with American students who have received training in working with Soviet Evangelicals. Have them introduce the students to various school personnel and orient them to the layout of the school campus..

- Be flexible. Handle Soviet Evangelicals needing special attention on an individual, case-by-case basis. If a Soviet Evangelical female is adamant about not taking P.E., for example, be willing to look into alternatives.

Issue 4: Lack of skills/background knowledge necessary for interacting in an American classroom.

Recommendations:

- Teach specific skills. Because of the differences between the Soviet and American 
approaches to learning, Soviet Evangelical students will probably be unfamiliar with the following skills:

-- Maintaining an organized notebook.

-- Meeting assignment deadlines.

-- Getting homework and in-class assignments after an absence.

-- Making their own choices, such as selecting electives for their class schedule.

- Teach cultural values.

-- It is acceptable to express one's opinion.

-- Overt discrimination toward other races and/or cultural groups is not acceptable.

-- Individual freedom is an important American value, but it is practiced within certain limitations.

Issue 5: Difficulty in establishing a trusting relationship with Soviet Evangelical students and parents.

\section{Recommendations:}

- Attend a Soviet Evangelical church service. Parents and students will have the opportunity to acquaint themselves with a teacher on their grounds. Instead of being seen as an authority figure representing the distrusted government, the teacher will be seen as a concerned educator. A healthy relationship between Soviet Evangelical parents, students, and teachers can then begin to develop.

- Use the church as a resource. When needing to speak with parents, use interpreters from the parents own church. Hearing information from someone they trust who is working with the American teacher, will most likely increase the parents' level of trust in the teacher.

- Encourage parental involvement. Soviet Evangelical parents were not welcome in Soviet schools. Teacher visits to homes were made to harass families. Inviting parents to their children's new school or having conferences with parents, either at their church or using a member of their church as interpreter, will again help to dispel the distrust many parents have of schools and teachers.

- Make Soviet Evangelical students feel a part of their new classroom. Take an interest in the stories they have to tell about themselves and their experiences in coming to America. 


\section{CHAPTER VIII}

\section{EPILOGUE}

In the year between the time the interviews with the nine participants took place and the study was completed, three students graduated, two dropped out, one transferred to a different school, and the rest are making progress towards graduation. The following describes the present-day lives of each of the study's participants:

\section{$\underline{\text { Alex }}$}

According to the ESL teacher, "Alex was doing fine and headed for graduation. Spring Term he dropped out." During this term, Alex began missing more and more school, citing "business trips to Spokane, WA" as the reason. Alex would never tell anyone what business he was involved in. The ESL teacher was frustrated and disappointed over this. She said Alex had developed a "dual personality". One day he was a fine student, then later, he was a difficult one. She felt he could have easily graduated, except that his many absences became more of a problem.

\section{$\underline{\text { Julia }}$}

Julia graduated from Devin High School and then moved to Clackamas, OR with her family. During the Christmas season, Julia was working at a store wrapping presents. The ESL teacher thought she was still working at the same shop. 


\section{Nick}

"Adorable" was the first word the ESL teacher used when speaking of Nick. He exited the ESL program at Devin and is now attending Clackamas High School and doing well, according to reports the ESL teacher has received.

\section{Maria}

Maria graduated from Devin, in spite of the ESL teacher's reservations about her English skills. Maria plans to work or to attend college, most likely a business school, and study secretarial skills. She also passed her driver's test after several failed attempts, partly due to language problems. The ESL teacher does not believe she will follow the path of her older sisters and marry soon. "She doesn't seem interested in that," she stated.

\section{Olga}

Olga completed her junior year and is on-track towards graduation. She is currently spending half of the school day at the school district's vocational skills center training to be a paralegal and studying desktop publishing. She still receives some ESL instruction. Like her sister, she also does not seem interested in marrying soon, according to the ESL teacher.

\section{Peter}

With only one semester left before graduation, Peter "disappeared". The ESL teacher was not sure of the reason, since Peter had exited ESL and she had little contact with him after that. As with Alex, she was disappointed in his dropping out because in spite of his poor attendance, he could have also graduated. 
Ven

Ven transferred to another high school in the Portland-Vancouver area because of his lack of academic success at Devin. The ESL teacher did not know how he was doing there. Before he left, Ven was still having difficulties in the ESL classroom. Skipping class was a problem, along with just being able to settle down and do his work. The ESL teacher felt that Ven "wanted to do well, but didn't have the skills."

\section{Dimitri}

Dimitri completed his junior year and the ESL teacher feels he will be able to graduate. He also moved up to the advanced section of ESL. While his classroom behavior continued to be a problem, the ESL teacher did notice some improvement, crediting the fact that Dimitri had "grown-up" a bit during the year. During his senior year, Dimitri will spend half of the school day at the skills center studying construction. Until recently he was working part-time at a local Taco Bell, but was fired due to poor attendance and "laziness on the job" as the ESL teacher described it.

\section{Yelena}

Yelena graduated the year the study was conducted. She has become very active in her church, working as a missionary. Most recently, she was raising money to return to Ukraine on a mission with her church. She was also doing janitorial work and planning to enter a local Bible college.

With the exception of Alex and Peter, who dropped out shortly before graduation, the ESL teacher characterizes all of these students as "successful". In spite of the rough start some of them experienced and the challenge some have posed in the 
ESL classroom, the teacher believes that all will be able to achieve a level of selsufficiency once they have graduated from high school. The Soviet Evangelical students who do not graduate and eventually drop-out of school are the ones who the ESL teacher and her classroom aide do not see on a daily basis. "When they are in ESL, we can keep an eye on them. Once they are out, some start sliding in their mainstream classes. Nobody tells anyone else that there's a problem." Providing support for Soviet Evangelical students once they leave the security of the ESL program is, according to the ESL teacher, the next phase of development for Devin High School. 


\section{REFERENCES}

Belozersky, I. (1989). Psychocultural frame of reference of refugee groups. Paper presented at "Making It in America". New York.

Berry, J.W. (1988). Acculturation and psychological adaptation: A conceptual overview. In J.W. Berry \& R.C. Annis, (Eds.). Ethnic Psychology: Research and practice with immigrants, refugees, native peoples, ethnic groups, and sojourners. Berwyn, PA: Swets North America, Inc.

Boekestijn, C. (1988). Intercultural migration and the development of personal identity. International Journal of Intercultural Relations, 12, 83-105.

Brown, H.D., (1987). Principles of language learning and teaching. Englewood Cliffs, NJ: Prentice Hall Regents.

Changes abroad confound U.S. policy. (1990). Congressional Quarterly, 48:8, 593-596.

Christian refugees from the Soviet Union. (1989). Weaton, IL: World Relief.

Graves, B. (1993, October 20). Widespread cheating common. Oregonian, p.A1.

Handleman, M., (Ed.). (1983). The new arrivals. Practice Digest, 5:4, 3-22.

Hardwick, S. (1993). Russian refugees. Chicago, IL: The University of Chicago Press.

Hoot, J. (1992). Understanding the special needs of former Soviet children. Childhood Education, Winter 1992, 82-85.

Irwin, D. (1993). Tips for working with eastern european students. Unpublished paper. Vancouver, WA: Vancouver School District.

Levinsky, A. \& Rubenstein, S. (1994, June 26). The new pilgrims. Oregonian, p.L1.

Mayr, S.M. (1992). Russian evangelical christian refugees. Unpublished paper. Vancouver, WA: Vancouver School District. 
McLoughlin, B. (1987). Theories of second language learning. New York: Hodder \& Stoughton.

Muckle, J. (1990). Portrait of a Soviet school under glasnost. New York: St. Martin's Press.

New Soviet refugee students in the schools. (1990). Context, 10, 11-13.

O'Donnel, L. (1992). Russian in a hurry. Portland, OR: Portland State University School of Extended Studies.

O'Neil, J. (1992). A counseling psychologist in the USSR as a Fullbright scholar. Paper presented at the Annual Convention of the American Psychiatry Association. Washington D.C. Eric Document Reproduction Service No. ED348638.

Richmond, Y. (1992). From nyet to da: Understanding the Russians. Yarmouth, ME: Intercultural Press, Inc.

Roberts, A. (1991). Internal-external locus of control and the life experiences of Soviet Pentecostal refugees in Portland, Oregon. Unpublished master's thesis.

Portland, OR: Portland State University.

Specific questions regarding Soviet Pentecostal students. (1993). Unpublished paper. Vancouver, WA: Vancouver School District.

Stevernik, L., ed. (1992). Guide to eastern european business education. The Netherlands: IMEC Publishing.

Valsamakis, A. (1992). School issues: Russian refugees. Unpublished paper. Portland, OR: Portland Public Schools.

Wiggins, P. (1994). Soviet Evangelical students in adult ESL classes: A case study. Unpublished master's thesis. Portland, OR: Portland State University.

Zvereff, A. (1992). Russian pentecostal students. Unpublished paper. Portland, OR: Portland Public Schools.

Zvereff, V. (1992). Why Soviet Pentecostal students do so poorly. Unpublished paper. Portland, OR: Portland Public Schools. 


\section{APPENDIX A}

\section{LETTER OF PURPOSE}

(The research site and all participants have been given pseudonyms to ensure confidentiality).

August 30, 1993

Dear Bill,

Sharon Link will be observing Soviet Pentecostal students in my classroom two or three days a week this semester and interviewing them after school. She is doing her Master's Thesis for completion of her MA in Teaching English to Speakers of Other Languages with certification in ESL at Portland State University.

Sharon has chosen to collect her data here because she worked with Susan and me as an ESL Staff Assistant 1991-92, our first year at Devin.

Hopefully, her completed project will be something that all teachers, administrators, and counselors can use as a resource when working with our Russian and Ukrainian students.

To indicate your approval, please sign at the bottom and return a copy to me for Sharon's professors.

Thank you,

Patricia Benko, ESL teacher

Approved by Bill Johnson, Principal 
APPENDIX B

SAMPLE OBSERVATION CODING SHEET

\begin{tabular}{|c|c|c|c|}
\hline$\overline{T I M E}$ & BEHAVIOR & TEACHER REACTION & STUDENT RESPONSE \\
\hline $7: 26$ & 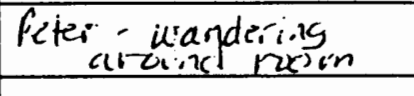 & Sit dow.n! & $\begin{array}{c}\text { Slowly ritums } \\
\text { te resk. }\end{array}$ \\
\hline \multirow[t]{4}{*}{$7: 30$} & Win-left rezm to & & \\
\hline & $\begin{array}{l}\text { locken. Stands actside } \\
\text { tolkeng, to Derith. }\end{array}$ & doesnit see & Ss come in. \\
\hline & 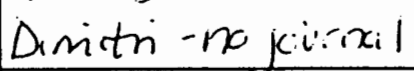 & the hour 30 sic $C K$ & Argives. Slouly \\
\hline & & & 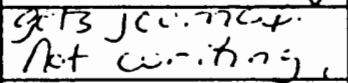 \\
\hline \multirow[t]{2}{*}{$7: 34$} & Alex + Valeri talking. & Alex! Serck him to & Goe's slowly \\
\hline & & back $x(0 . n)$ & \\
\hline \multirow[t]{2}{*}{$7: 35$} & Ven- no jaicinal. & What are gea doing? & O.41 thine- \\
\hline & & Where is you jocinal? & hag to get it. \\
\hline \multirow[t]{3}{*}{$7: 35$} & Peter + Vollevi-no & $d o r \sin t$ & \\
\hline & $\begin{array}{l}\text { joirncies uriting } \\
\text { doinc, wolk fiom }\end{array}$ & & \\
\hline & $\begin{array}{l}\text { othite (ans) V. } \\
\text { drinimg. }\end{array}$ & & \\
\hline \multirow[t]{6}{*}{$7: 45$} & Vitali - jost sitting & I 11 give yai a & Miakes face of \\
\hline & at desk & $\begin{array}{l}\text { "oliet place tocuizh } \\
\text { conselusen! }\end{array}$ & Teaclsi to other \\
\hline & & & dest. \\
\hline & Alex tulking lisil. & Alex, is he finisled? & Gontinie cinin \\
\hline & $\begin{array}{l}\text { Alix-out of siat } \\
\text { wi kicie ivion }\end{array}$ & Then leave hin & thix gors bxick to \\
\hline & & alone & desx-nct bact \\
\hline
\end{tabular}


APPENDIX C

\section{LANGUAGE LEARNING PREFERENCE SURVEY}

\section{HOW DO YOU LIKE TO LEARN BEST?}

1. In English class, I like to learn by reading.

2. In class, I like to listen to and use cassettes.

3. In class, I like to leam by games.

4. In class, I like to leam by conversations.

5. In class, I like to learn by pictures, films, video

6. I want to write everything in my notebook.

7. I like to have my own textbook.

8. I like the teacher to explain everything to us.

9. I like the teacher to give us problems to work on.

10. I like the teacher to help me talk about my interests

11. I like the teacher to tell me all my mistakes.

12. I like the teacher to let me find my mistrikes.

13. I like to study English by myself (alone).

14. I like to learn English by talling in pairs

15. I like to learn English in small groups.

16. I like to learn English with the whole class.

17. I like to go out with the class and practice English.

18. I like to study grammar.

19. I like to learn many new words.

20. I like to practice the sounds and pronumaiation.

21. I like to learn English words by seeing them.

22. I like to learn English words by hearing them.

23. I like to learn English words by doing something.

24. At home, I like to learn by reading newspapers, etc.

25. At home, I like to learn by watching TV in English.

26. At home, I like to learn by using cassettes.

27. At home, I like to learn by studying English books.

28. I like to learn by talking to friends in English.

29. I like to learn by watching/listening to Americans.

30. I like to learn by using English in stores/buses, etc.

$\begin{array}{llll}\text { no a little } & \text { good best } \\ \text { no a little } & \text { good best } \\ \text { no a little } & \text { good best } \\ \text { no a little } & \text { good } & \text { best } \\ \text { no a little } & \text { good best } \\ \text { no a little } & \text { good } & \text { best } \\ \text { no a little } & \text { good best } \\ \text { no a little } & \text { good best } \\ \text { no a little } & \text { good best } \\ \text { no a little } & \text { good best } \\ \text { no a little } & \text { good best } \\ \text { no a little } & \text { good bed } \\ \text { no a little } & \text { good best } \\ \text { no a little } & \text { good best } \\ \text { no a little } & \text { good best } \\ \text { no a little } & \text { good beat } \\ \text { no a little } & \text { good best } \\ \text { no a little } & \text { good best } \\ \text { no a little } & \text { good best } \\ \text { no a little } & \text { good best }\end{array}$




\title{
APPENDIX D
}

\section{INTERVIEW GUIDING QUESTIONS}

\author{
Date \\ Student
}

1. Personal Information:

Age_ Grade____ Age when emigrated

Religion_Last grade completed in former

S.U. No. members in family

Siblings_ Rank among siblings

2. How did you feel when told going to emigrate to U.S.?

3. Describe first day in new American school?

4. What are differences between U.S. and Soviet schools?

5. What was biggest adjustment to make to American schools?

6. What like best/least about school and ESL?

7. Describe these behaviors-- talking during class, sharing answers (cheating), resistance to authority.

8. Why so many absences?

9. How feel about non-Soviet ESL classmates?

10. How do your religious beliefs affect your behavior at school?

11. What like best/least about American culture?

12. Do you feel you have changed since living in the U.S.? How so?

13. How do you see your life five years from now?

14. Do you want to return to the former Soviet Union to Iive? 


\section{APPENDIX E}

\section{SOVIET CONSERVATIVE RELIGIOUS GROUPS VERSUS AMERICAN SOCIAL VALUES}

\section{TRADITIONAL}

(Some common attitudes of conservative religious groups)

1) A lifelong attachment to family and community is expected

2) The meaning of life is explained by God

3) Cooperation between family is very important

4) Separation of men's and women's roles is natural

5) Strictness in childrearing is good

6)A parent knows what is best for child-youth

7) A mother should be loved best

8) A child needs to understand that work and school are serious

9) Older people are wiser than young

10) A parent must approve of friends

11) Boys and girls should have separate toys

12) A child should feel valued as a member of family

13) It is good when a young person is modest
DEMOCRATIC

(Common attitudes in modern American society)

1) Early separation and finding own way of life is good

2) Life's mystery is found in scientific knowledge

3) An individual should make their own effort to get ahead

4) It's best when men and women share roles

5) Tolerance is good in childrearing

6) A youth knows what's needed for him/herself

7) It is healthy to be attached to others besides mother

8) A child can have fun while learning and working

9) A child may have wisdom as well as an adult

10) A child/youth can choose their own friends

11) All children can play with the same toys

12) A youth needs to feel special as an individual

13) A success is not afraid to stand out 
14) Children enjoy complete dependence on parents

15) Faith in God is the best guide in living

16) It is right to respect all adults

17) Taking care of an older parent is right

18) The future is in God's hands

19) Everything a person does reflects on their family

20) If the family opposes a decision, then maybe the decision should be changed

21) Adult children should live with or visit parents regularly

22) Relatives are always more important than friends

From: Valsamakis, 1992.
14) Children like some independence from parents

15) There are different paths to moral life

16) Respect those adults you admire

17) Older people need to plan for the future

18) The future depends on how you plan today

19) Each individual is responsible for their own actions

20) Decide yourself because you have to live with the decisions

21) Adult children should be involved in their own lives

22) Friends are as important as relatives 


\section{APPENDIX F}

\section{INDIVIDUALIST VERSUS COLLECTIVIST VALUES}

\section{Individualist Orientation}

Reflects preference for autonomy in relation to groups.

Smallest unit of survival: self.

Places personal goals above group goals.

More inner directed in relation to goal.

High evaluation of challenge, personal pleasure, freedom.

Feeling that most events are internally controlled changed through action.

Authority and power relationships subject to analysis, acceptance of authority less easily.

Expects to assert own needs in strategy approach to social environment.

Some tolerance for uncertainty, ability to stand tension, risk for results.

Rewards follow from actions, doing.

Information comes through senses, scientific examination.

Unclear norms.

Strangers judged by accomplishments.

\section{Collectivist Orientation}

Reflects preference for interdependence with groups.

Smallest unit: collective (maybe family, other unit).

Subordinate personal goals to collective, group goals.

Group norms internalized: norms of the group become part of self.

Value placed on duty, use of skills, altruism.

Sense of externally shaped reality; forces greater and outside self dictate what will be.

Acceptance of power and authority as inevitable. Rank has privilege.

Passive expectation that needs will be met by authority.

Uncertainty avoided by seeking structure, security, control by others.

Rewards follow from chance, fate.

Information bestowed ideologically, through leaders.

Clear norms.

Strangers differentiated based on age, sex, religion, rank. 
Can be open to outsiders, trust strangers, accept information, help.

Individual independence, anti-authoritarian values.

Pragmatism -- start with observations/ facts and generalize. Sees ideologist as impractical, fuzzy, unrealistic.

Emphasis on future, world as changing.

Informal but reserved; controlled emotionally.

Change in leadership often does not affect status quo.

Horizontal relationships have most power. Friend to friend / spouse to spouse.

Prefer short term, multiple associations. First stages of relationships are easy. Later stages of intimacy difficult.

Meaning of self reliance is getting to do what one wants.

Equity: each gets according to what one contributes.

Self-Governance -- Self Makes Rules.
Low trust of outsiders, seek protection from one's known group to carry out transaction.

Obedience to authority, less accountable, more power.

Ideology -- start with theory and fit in facts/evidence. Sees pragmatist as interested in details, trivial.

Emphasis on past, accomplishments, precedents, continuity.

More formal in observation of social roles but less inhibited emotionally.

Change in groups, leadership produce change in collective mentality.

Vertical relationships have most power. Parent to child / Boss to employee.

Would rather have long duration relationships, resist casual associations. First stages difficult. Move easily into intimacy.

Meaning of self reliance: to not place burden on others in group.

Equality: distribution of resources same for everyone.

Obedience -- Accept Rules of Others.

From: Valsamakis, 1992. 